\title{
Synthesis of Indoloquinolines: An Intramolecular Cyclization Leading to Advanced Perophoramidine-Relevant Intermediates
}

\author{
Craig A. Johnston, David B. Cordes (D), Tomas Lebl, Alexandra M. Z. Slawin (D) and Nicholas J. Westwood*(D) \\ School of Chemistry and Biomedical Sciences Research Complex, University of St. Andrews and EaStCHEM, \\ North Haugh, St. Andrews KY16 9ST, UK; craig.johnston85@gmail.com (C.A.J.); \\ dbc21@st-andrews.ac.uk (D.B.C.); t112@st-andrews.ac.uk (T.L.); amzs@st-andrews.ac.uk (A.M.Z.S.) \\ * Correspondence: njw3@st-andrews.ac.uk; Tel.: +44-1334-463816
}

Citation: Johnston, C.A.; Cordes, D.B.; Lebl, T.; Slawin, A.M.Z.; Westwood, N.J. Synthesis of Indoloquinolines: An Intramolecular Cyclization Leading to Advanced Perophoramidine-Relevant Intermediates. Molecules 2021, 26 , 6039. https://doi.org/10.3390/ molecules26196039

Academic Editors: Gianfranco Favi, William T. A. Harrison, R. Alan Aitken and Paul Waddell

Received: 14 September 2021

Accepted: 1 October 2021

Published: 5 October 2021

Publisher's Note: MDPI stays neutral with regard to jurisdictional claims in published maps and institutional affiliations.

Copyright: (C) 2021 by the authors Licensee MDPI, Basel, Switzerland. This article is an open access article distributed under the terms and conditions of the Creative Commons Attribution (CC BY) license (https:// creativecommons.org/licenses/by/ $4.0 /)$.
Abstract: The bioactive natural product perophoramidine has proved a challenging synthetic target. An alternative route to its indolo[2,3-b]quinolone core structure involving a N-chlorosuccinimdemediated intramolecular cyclization reaction is reported. Attempts to progress towards the natural product are also discussed with an unexpected deep-seated rearrangement of the core structure occurring during an attempted iodoetherification reaction. X-ray crystallographic analysis provides important analytical confirmation of assigned structures.

Keywords: perophoramidine; natural product; Claisen rearrangement; indoloquinoline; intramolecular cyclization; $X$-ray structure

\section{Introduction}

Attempts to prepare complex bioactive natural products often test synthetic methodology under very challenging circumstances. In addition, unexpected outcomes, in what initially look like simple transformations, frequently occur and provide interesting analytical conundrums. One approach to solving these structural questions is the use of small-molecule X-ray crystallography which continues to play an essential role in developing routes to complex molecules. Through collaborations, such as ours with Professor Alexandra Slawin, difficult analytical challenges are frequently solved with apparent ease. For anyone who has had the pleasure to work with someone with Professor Slawin's level of expertise, the phrase "Oh of course Alex, now you've pointed it out that has to be the structure" will probably be familiar!

The structure of the natural product perophoramidine $\mathbf{1}$ (Scheme 1) was first reported in 2002 by Ireland [1] although earlier biosynthetic proposals, synthetic and small molecule X-ray crystallographic work had sparked interest in closely related alkaloids [2-10]. To date, a number of elegant total syntheses of perophoramidine $\mathbf{1}$ have been reported [11-16] along with a range of other attempts [17,18]. In addition, in their initial report, Ireland et al. reported the dehalogenation of perophoramidine $\mathbf{1}$ under hydrogenation conditions using $\mathrm{HCO}_{2} \mathrm{NH}_{4}$ and $\mathrm{Pd} / \mathrm{C}$ in $\mathrm{MeOH}$. This led to the formation of a compound that they named dehaloperophoramidine $\mathbf{2}$ (Scheme 1) [1]. Additional syntheses of compound $\mathbf{2}$ have been reported [19-22], with one of these routes to 2 being developed in our laboratory [21]. As our studies to 2 progressed, investigations into the synthesis of the halogen-containing 1 were also carried out.

Here, we report the successful synthesis of the halogen-containing analogue 3 of compound $\mathbf{4}$, which was a key intermediate in our synthesis of 2 (Scheme 1) [21]. Attempts to progress forward from 3 towards 1, using an alternative route to that reported by us for the synthesis of 2 [21], are also described. In addition, we include the structural assignment of two of the prepared compounds by small-molecule X-ray crystallographic analysis, bringing to 18 the total number of times this technique has guided this overall program 
of work (for the previous small molecule X-ray crystallographic structures see CCDC 737646-737648, 1486344, 1478152-4, 1582892-7 and 1811882-4).

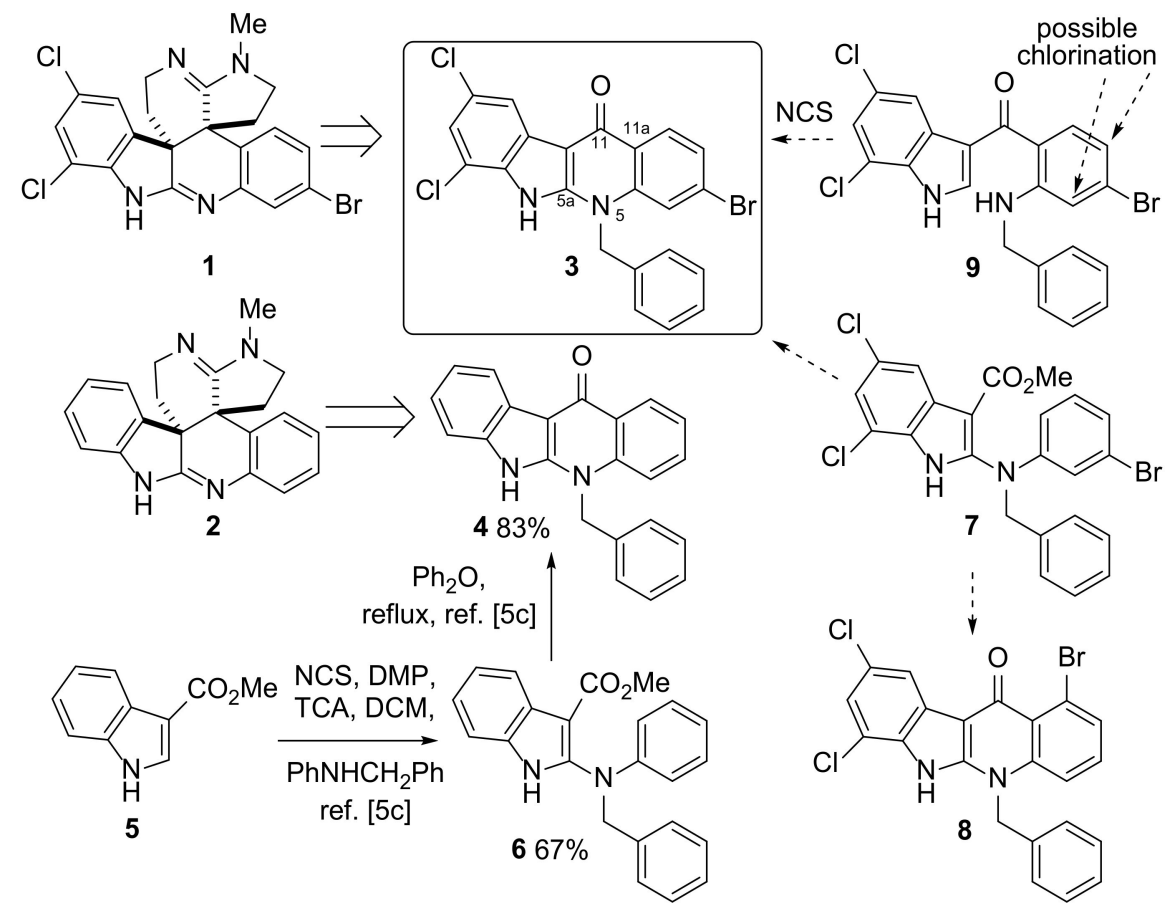

Scheme 1. Structures of the natural product perophoramidine $\mathbf{1}$ and the product prepared by Ireland et al. [1] following dehalogenation, dehaloperophoramidine 2. Previous reports [5c] described the synthesis of $\mathbf{4}$ via a NCS-mediated coupling reaction of $\mathbf{5}$ and subsequent cyclization of $\mathbf{6}$. 4 was then converted to 2 [21]. In this work, access to the analogous intermediate 3 was explored with two possible routes either via 7 or an intramolecular NCS-mediated cyclization of 9 considered. An alternative product, compound $\mathbf{8}$, from a potential cyclization reaction of $\mathbf{7}$ was possible. Chlorination of the aniline ring in 9 was also a potential side reaction. $\mathrm{NCS}=\mathrm{N}$-chlorosuccinimide; DMP $=\mathrm{N} \mathrm{N}^{\prime}-$ dimethylpiperazine; TCA = trichloroacetic acid.

\section{Results}

\subsection{Proposed Route to Halogenated Intermediate 3}

We have previously reported [21] a robust and scalable route to the indolo[2,3$b$ ]quinoline core structure of 4 using a $N$-chlorosuccinimide (NCS)-mediated coupling of methyl indole-3-carboxylate (5) with $\mathrm{N}$-benzylaniline followed by cyclization of the product 6 in refluxing diphenyl ether (Scheme 1) [23]. This reaction sequence proved a suitable starting point for the synthesis of dehaloperophoramidine 2 [21]. Whilst this approach was relatively straightforward and high yielding in the case of 4 , it seemed likely that the analogous reaction using substrate 7 with the required halogenation pattern to prepare perophoramidine 1 would lead to the formation of regioisomers 3 and $\mathbf{8}$ (Scheme 1). It was envisaged that separation of $\mathbf{3}$ and $\mathbf{8}$ would prove challenging as these type of compounds exhibit low solubility in organic solvents.

To avoid this issue, an alternative approach was proposed involving a NCS-mediated cyclization reaction of substituted indole 9 to form the N5-C5a bond in 3 after the C11C11a bond. This is an intramolecular version of the reaction used to form $\mathbf{6}$ (Scheme 1). NCS-mediated intramolecular cyclization reactions have recently been used to form a $\mathrm{C}-\mathrm{N}$ bond at the indole 2-position in the total synthesis of (-)-chaetominine (10) [8] with tetrahydro- $1 H$-pyrido[2,3- $b$ ]indole (11) being prepared from substituted indole 12 using NCS (1.3 equiv.) and $\mathrm{Et}_{3} \mathrm{~N}$ (4 equiv.) in DCM in 52\% yield (Scheme 2). One possible challenge with this approach in our system was competing chlorination in the aniline ring 
in 9 (Scheme 1). Given difficulties in predicting the result of this competition a priori, it was decided to investigate this proposed route to 3 .

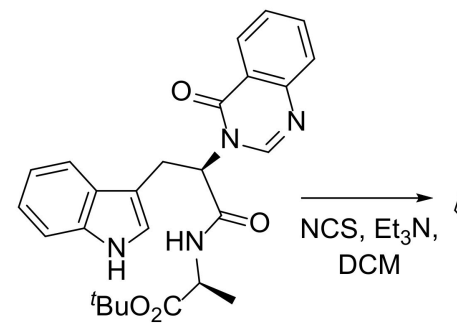

12

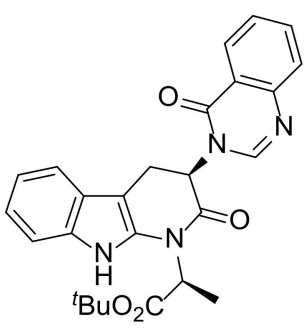

$1152 \%$

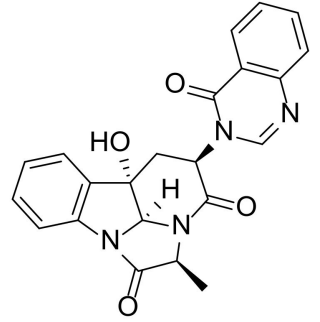

$(-)$-chaetominine $\left({ }^{10}\right)$

Scheme 2. Reported synthesis of $\mathbf{1 1}$ via a NCS-mediated formation of the $\mathrm{C}-\mathrm{N}$ bond at the indole 2-position during the preparation of the natural product (-)-chaetominine (10) [24].

\subsection{Synthesis of Halogenated Intermediate 3}

Whilst several methods are available for the synthesis of 5,7-dichloroindole (13) [24-28] including electrochemical-mediated cyclization [25] and gold-catalyzed annulation of the corresponding 2-alkynylaniline [26], it was decided to use the Bartoli indole synthesis $[27,28]$ as multi-gram quantities of $\mathbf{1 3}$ were required (Scheme 3). Reaction of 2,4dichloronitrobenzene (14) with vinylmagnesium chloride [28] gave indole $\mathbf{1 3}$ with key steps in the process involving a [3,3]-sigmatropic rearrangement followed by cyclization onto the resulting aldehyde to form the 5-membered ring. The yield of this reaction was relatively low (48\%, in line with the literature precedent [28]); however, the starting materials were readily available and the reaction could be carried out to give almost $9 \mathrm{~g}$ of 13 . Indole 13 was subsequently converted to aldehyde 15 using a Vilsmeier-Haack reaction [29] and Boc protection of the indole nitrogen using di-tert-butyl dicarbonate $\left(\mathrm{Boc}_{2} \mathrm{O}\right)$ in the presence of 4-dimethylaminopyridine (DMAP) formed 16 in high yield (Scheme 3).<smiles>C=CN(C)C(=O)c1ccc(Cl)cc1[N+](=O)[O-]</smiles>

14<smiles>Clc1cc(Cl)c2[nH]ccc2c1</smiles>

$1348 \%$

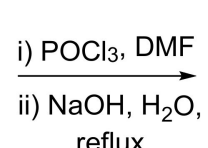
reflux

$$
1587 \%
$$

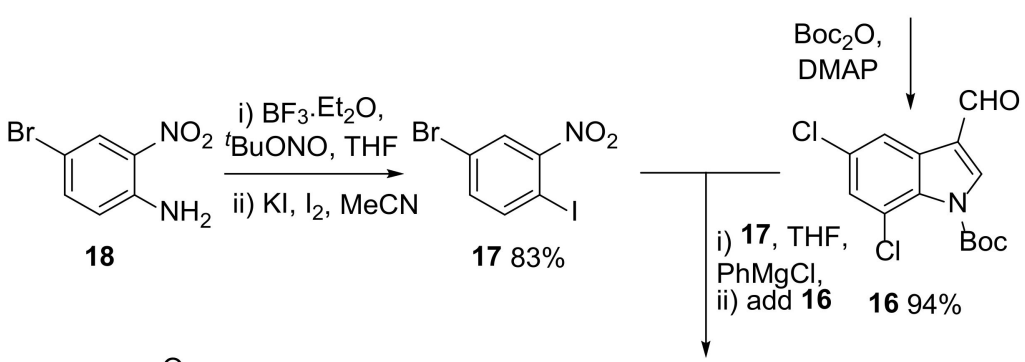

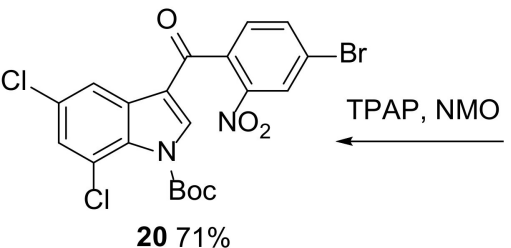<smiles>O=C([O-])n1cc([C@@H](O)c2ccc(Br)cc2[N+](=O)[O-])c2cc(Cl)cc(Cl)c21</smiles>

Scheme 3. Synthesis of ketone $\mathbf{2 0}$ involving generation of indole $\mathbf{1 3}$ using a Bartoli reaction [27,28] and a Knochel-type coupling reaction. TPAP = tetrapropylammonium perruthenate; $\mathrm{NMO}=\mathrm{N}$ methylmorpholine N-oxide. 
Aryl iodide 17 was then synthesized from 18 in $83 \%$ yield using a literature procedure (Scheme 3) [30]. Having prepared intermediates 16 and 17, a Grignard-mediated coupling reaction was attempted. This reaction was based on a method reported by Knochel et al. in which aryl rings containing an iodine atom ortho to a nitro group can undergo I-Mg exchange when treated with phenylmagnesium chloride [31,32]. The resulting Grignard reagent can then react with an electrophile to form a new carbon-carbon bond. Interestingly, more reactive Grignard reagents such as methyl magnesium chloride react with the nitro group, leading to complex mixtures of products. The reaction is also reported to be unsuccessful when meta- or para-iodonitrobenzenes are used [31,32], leading to the proposal that chelation of the nitro group to the magnesium atom stabilizes the ortho-substituted Grignard reagent. The treatment of iodide 17 with phenylmagnesium chloride at $-40^{\circ} \mathrm{C}$ for $1 \mathrm{~h}$ followed by reaction with aldehyde $\mathbf{1 6}$ gave alcohol $\mathbf{1 9}$ (racemate, Scheme 3) in excellent yield, even on a multiple-gram scale. Alcohol 19 was then oxidized to ketone 20 using tetrapropylammonium perruthenate (TPAP, $5 \mathrm{~mol} \%$ ) and co-oxidant $\mathrm{N}$-methylmorpholine $\mathrm{N}$-oxide (NMO) (Scheme 3) [33].

Attempts were made to reduce the nitro group to the corresponding amine and remove the Boc protecting group in one step by refluxing 20 in acetic acid and ethanol in the presence of iron powder. However, this reaction produced a mixture of the expected product 21 and Boc protected 22. A two step protocol using iron in acetic acid and ethanol followed by treatment of purified 22 with TFA in DCM gave $\mathbf{2 1}$ in an excellent yield over the two steps (Scheme 4). The required reductive N-benzylation of $\mathbf{2 1}$ proved more challenging. When $\mathbf{2 1}$ was heated with benzaldehyde in refluxing toluene for six hours followed by the addition of sodium triacetoxyborohydride (STAB) the required product 9 was obtained in only moderate yield presumably due to the relatively poor nucleophilicity of the aniline nitrogen in $\mathbf{2 1}$ disfavouring initial imine formation. An alternative improved procedure based on the report of Boros et al. [34] was eventually found. This involved the additional use of TFA and so enabled telescoping of the conversion of $\mathbf{2 2}$ to $\mathbf{9}$ which after optimization of this reaction (a second aliquot of the STAB/TFA solution after $30 \mathrm{~min}$ ) enabled the formation of $\mathbf{9}$ from $\mathbf{2 2}$ to $68 \%$ with a small quantity of $\mathbf{2 1}$ also being obtained (Scheme 4).

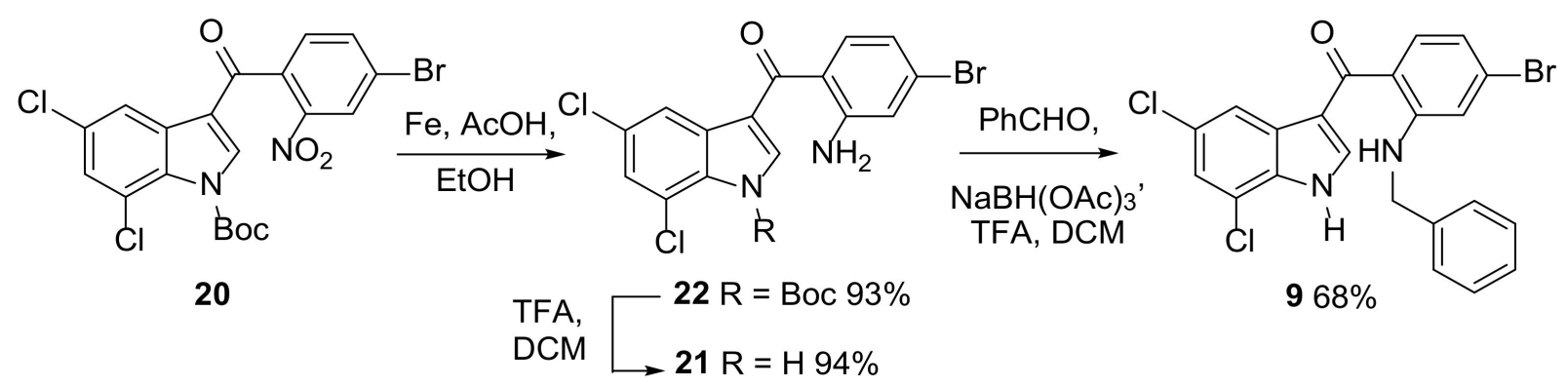

Scheme 4. Nitro group reduction and reductive amination.

After carrying out a series of model studies (see Supplementary Material), a NCSmediated cyclization of $\mathbf{9}$ was attempted. The initial conditions used were NCS (2.0 equiv.) and DMP (0.56 equiv.) in DCM at room temperature overnight. After stirring for $28 \mathrm{~h}$, it was observed that a small amount of precipitate was formed. The precipitate was isolated by filtration, washed with DCM and analyzed by ${ }^{1} \mathrm{H}$ NMR in d6-DMSO (Figure S2). The NMR and mass spectrometric analysis was consistent with the presence of two compounds with $\mathrm{m} / \mathrm{z}$ values equal to the required product 3 and a chlorinated analogue of 3 (assigned structure 23 (Scheme 5 and Figure S3), vide infra). Analysis of the filtrate and washings from the reaction indicated that again two main compounds were present, one of which was unreacted $\mathbf{9}$. The second compound was assigned as $\mathbf{2 4}$ (Scheme 5), which was presumably formed by NCS-mediated chlorination at the aniline 4-position rather than at the indole 3-position of $\mathbf{9}$. The isolation of $\mathbf{2 4}$ also led to the proposal that the unidentified chlorinated analogue of 3 present in the precipitate was in 
fact $\mathbf{2 3}$, the cyclized version of $\mathbf{2 4}$. To confirm this, a small-scale reaction of $\mathbf{2 4}$ with NCS and base was carried out, giving 23 (Scheme 5, Figure S3 and Supplementary Material for protocols and analytical data for 23 and 24 ).

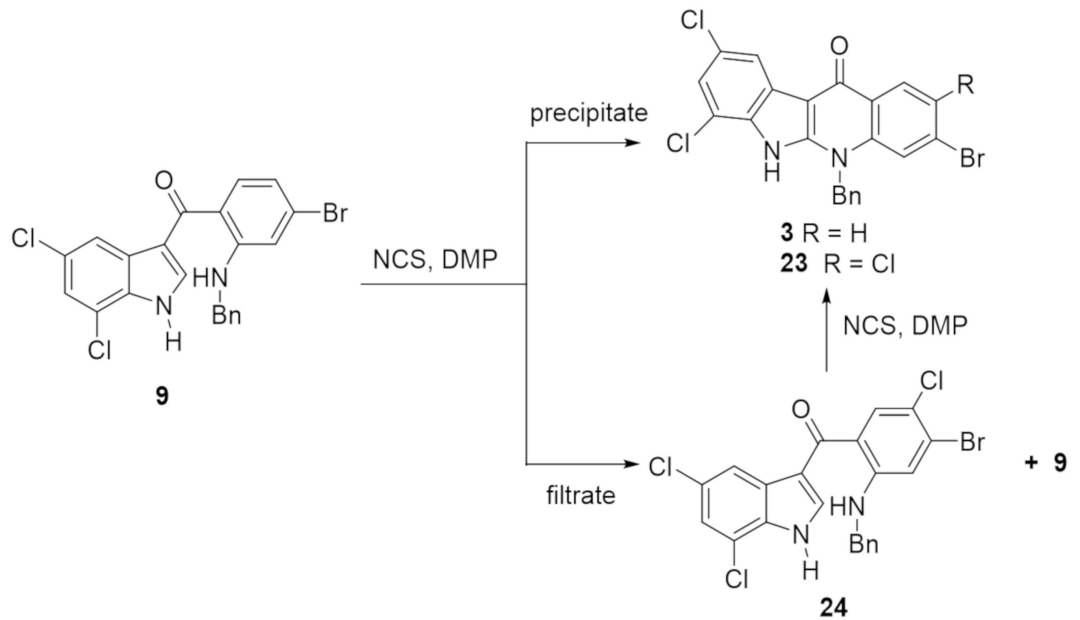

Scheme 5. Preliminary attempts at NCS-mediated cyclization of 9 using NCS (2.0 equiv.), DMP ( 0.56 equiv.) in DCM at room temperature for $28 \mathrm{~h}$ led to formation of a precipitate that contained the desired cyclized product $\mathbf{3}$ and a second product assigned as $\mathbf{2 3}$ (Figure S3, see Supplementary Material for analytical data for 23 and 24). 23 was independently prepared from an isolated sample of 24 (NCS (1.0 equiv.), DMP (0.56 equiv.) in DCM at room temperature for $16 \mathrm{~h}$ ). Significant optimization of this reaction was required.

Optimization of this reaction started with a solvent screen based on literature precedent $[23,24,35,36]$. The reaction of 9 with NCS (1.0 equiv.) and DMP (0.56 equiv.) was carried out in seven common solvents (DCM, MeOH, acetone, THF, $\mathrm{CH}_{3} \mathrm{CN}$, hexane and toluene) and the amount of precipitate isolated and the ratio of 9:24 in the filtrates was determined (Table S1). Acetonitrile was judged as the preferred solvent as the largest amount of precipitate was formed (cyclized products, Table S1, Entry 5). As related reactions have been reported using a range of bases [23,35-40], it was decided to react 9 with NCS (1.2 equiv.) in acetonitrile using six different bases (DMP, NaH, $\mathrm{Et}_{3} \mathrm{~N}, \mathrm{DMAP}$, DIPEA and pyridine, Table S2). In brief, the use of $\mathrm{Et}_{3} \mathrm{~N}$ gave the highest product yield (48\%) with only the required 3 being present in the precipitate and starting material 9 being the dominant product in the filtrate (Table S2, Entry 3). Further optimization of this reaction found that when 2.4 equivalents of both NCS and $\mathrm{Et}_{3} \mathrm{~N}$ were used at room temperature for $18 \mathrm{~h}, 3$ could be isolated in $55 \%$ yield with $9(21 \%)$ recovered on purification by column chromatography of the filtrate (Scheme 6 and Supplementary Material demonstrating the reproducibility of this reaction up to a $2 \mathrm{~g}$ scale). 


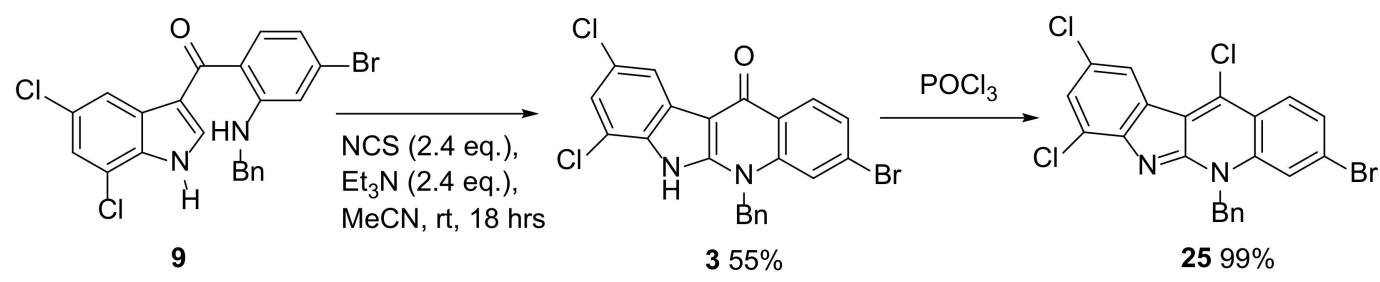<smiles>C=CCOc1c2c3cc(Cl)cc(Cl)c3nc-2n(Cc2ccccc2)c2cc(Br)ccc12</smiles><smiles>C=Cc1cc(Cl)cc(Cl)c1C1C(=O)c2ccc(Br)cc2N(Cc2ccccc2)C1=O</smiles>

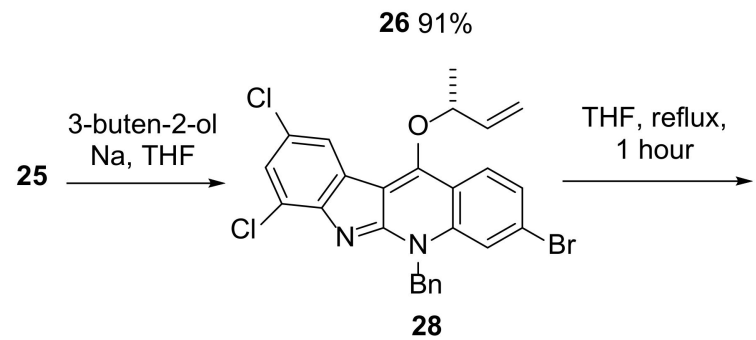<smiles></smiles>

Scheme 6. Optimized conditions for the conversion of 9 to 3 and instalment of an all-carbon quaternary center in compounds 27 and 29. Insights into the impact of the halogen substituents on both the addition-elimination and Claisen rearrangement steps were gained.

\subsection{Installation of the First All-Carbon Quaternary Center and X-ray Structure Determination of Advanced Intermediate $\mathbf{2 7}$}

After developing the route to ketone 3, the instalment of the first of the all-carbon quaternary centers (Schemes 1 and 6) present in perophoramidine $\mathbf{1}$ was achieved over 3 steps. Reaction of 3 with $\mathrm{POCl}_{3}$ gave 25 in almost quantitative yield. Substitution of one of the chlorines in $\mathbf{2 5}$ using sodium allyloxide gave allyl ether $\mathbf{2 6}$ (Scheme 6) which underwent Claisen rearrangement to form ketone 27 on heating at reflux in THF for $12 \mathrm{~h}$. Recrystallization of $\mathbf{2 7}$ provided crystals suitable for X-ray crystallographic analysis, which enabled confirmation of its structure (Figure 1). This three-step sequence was also successful when the alkoxide formed from the reaction of racemic 3-buten-2-ol with sodium was used. As observed previously in the dehalo system (Scheme S4) [21], the Claisen rearrangement of the crotyl-containing $\mathbf{2 8}$ generated from $\mathbf{2 5}$ was feasible at room temperature (unlike allyl-containing $\mathbf{2 6}$ which does not rearrange at all at room temperature) and as a result it was not possible to isolate $\mathbf{2 8}$ in pure form. Heating the obtained sample of predominantly 28 at reflux in THF only required $1 \mathrm{~h}$ for full conversion to 29 in $75 \%$ yield over the two steps (c.f. the $12 \mathrm{~h}$ at reflux in THF required for complete conversion of 26 to 27 and the $5 \mathrm{~h}$ required in the analogous reaction in the crotyl-dehalo series, Scheme S4). It is clear that the presence of the halogens in $\mathbf{2 8}$ accelerated the Claisen rearrangement. In this sequence it was also interesting to note that the alkoxide addition-elimination reactions of $\mathbf{2 5}$ to give $\mathbf{2 6}$ or $\mathbf{2 8}$ proceeded much faster than the corresponding reaction of dehalo analogue which required $18 \mathrm{~h}$ to convert fully [23]. This is likely due to the electron-withdrawing effect of the halogen substituents in $\mathbf{2 5}$ promoting nucleophilic addition of the alkoxide. Although the synthesis of intermediate $\mathbf{2 9}$ was carried out in such a way that racemic product was obtained, the use of enantiomerically enriched (R)-3-buten-2-ol would enable the formation of the $\mathrm{C}-10 \mathrm{~b}$ quaternary center with the correct absolute stereochemistry required for an asymmetric synthesis of perophoramidine $\mathbf{1}$ [23]. 


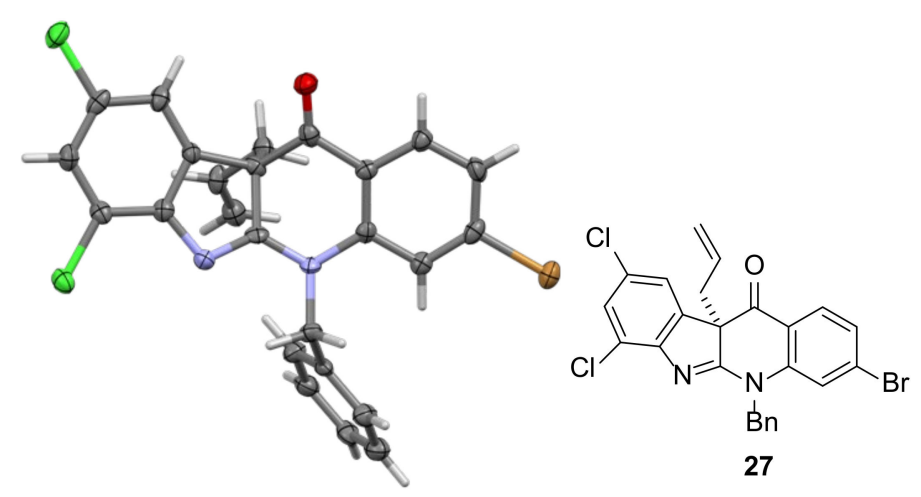

Figure 1. A view of the X-ray crystal structure of $\mathbf{2 7}$ (ellipsoids drawn at the $50 \%$ probability level) used to confirm its structure.

\subsection{Attempted Progress towards Perophoramidine $\mathbf{1}$}

The second half of this report briefly describes two approaches that were attempted to progress from advanced synthetic intermediates $\mathbf{2 7}$ and $\mathbf{2 9}$ towards perophoramidine 1. Whilst ultimately unsuccessful, these approaches did provide additional insights into the inherent reactivity of this complex system. One of the initial strategies employed by others [17,41] and us [42] for the synthesis of $\mathbf{1}$ and $\mathbf{2}$ involved the preparation of a C11ester-containing intermediate, in our case, of general structure 30 (Scheme 7and Scheme S5). The approach attempted here for installing a C11-ester involved reaction of the previously prepared 29 with in situ-generated chloromethyl lithium to form epoxide $\mathbf{3 1}$ in good yield (Scheme 7). The relative stereochemistry of $\mathbf{3 1}$ was tentatively assigned based on the absence of a nOe correlation between the $\mathrm{CH}_{2}$ of the epoxide and any of the protons of the crotyl chain. In addition, the assigned stereochemistry in $\mathbf{3 1}$ was expected due to the attack of the chloromethyl lithium from the least hindered face of the molecule as was observed in previous studies in which proof of structure had been obtained through small-molecule Xcrystal structure analysis of the analogous dehalo-epoxide [21]. Reductive opening of 31 to give 32 was then achieved using excess boron trifluoride and sodium cyanoborohydride in moderate yield. It was believed that this reaction proceeded with inversion of configuration at the C-11 stereocenter due to hydride attack occurring from the least hindered face, again consistent with previously reported studies in which small-molecule X-ray analysis of a related dehalo-analogue had been achieved [42]. Unfortunately, the results obtained from the Jones oxidation [43] of 32 were different to those of the previously reported non-halogenated alcohols [42]. Following the reaction by LC-MS showed that after just 5 min reaction time, 32 was almost completely consumed with a number of different product peaks being observed in the LC-MS spectrum. From the complex mixture of products obtained at this time point, evidence for the presence of 33 was obtained. After an increased reaction time $(5 \mathrm{~h})$, the initially complex mixture simplified with the major product being assigned as the decomposition product 34 (Scheme 7 and Figure S4, observed $m / z=501.17[\mathrm{M}+\mathrm{H}]^{+}$; theoretical $\mathrm{m} / \mathrm{z}$ for formation of $34, \mathrm{C}_{23} \mathrm{H}_{13}{ }^{81} \mathrm{Br}^{35} \mathrm{Cl}_{2} \mathrm{~N}_{2} \mathrm{O}_{2}[\mathrm{M}+\mathrm{H}]^{+}$ 500.96). No evidence for the presence of 33 in the reaction mixture at the $5 \mathrm{~h}$ time point was found.

As conversion of $\mathbf{3 2}$ to 34 clearly involved loss of the crotyl group (for one possible mechanism see Scheme S6), it was next decided to develop the crotyl chain in $\mathbf{2 9}$ (or in fact the allyl chain in 27, Scheme 8) by reacting the double bond. Building on an approach previously reported by us in the dehalo series [44], 35 became the new target molecule. Subsequent conversion of $\mathbf{3 5}$ to $\mathbf{3 6}$ could provide an approach to perophoramidine $\mathbf{1}$ by differentiating between the two allyl groups as seen in a related system [21]. 

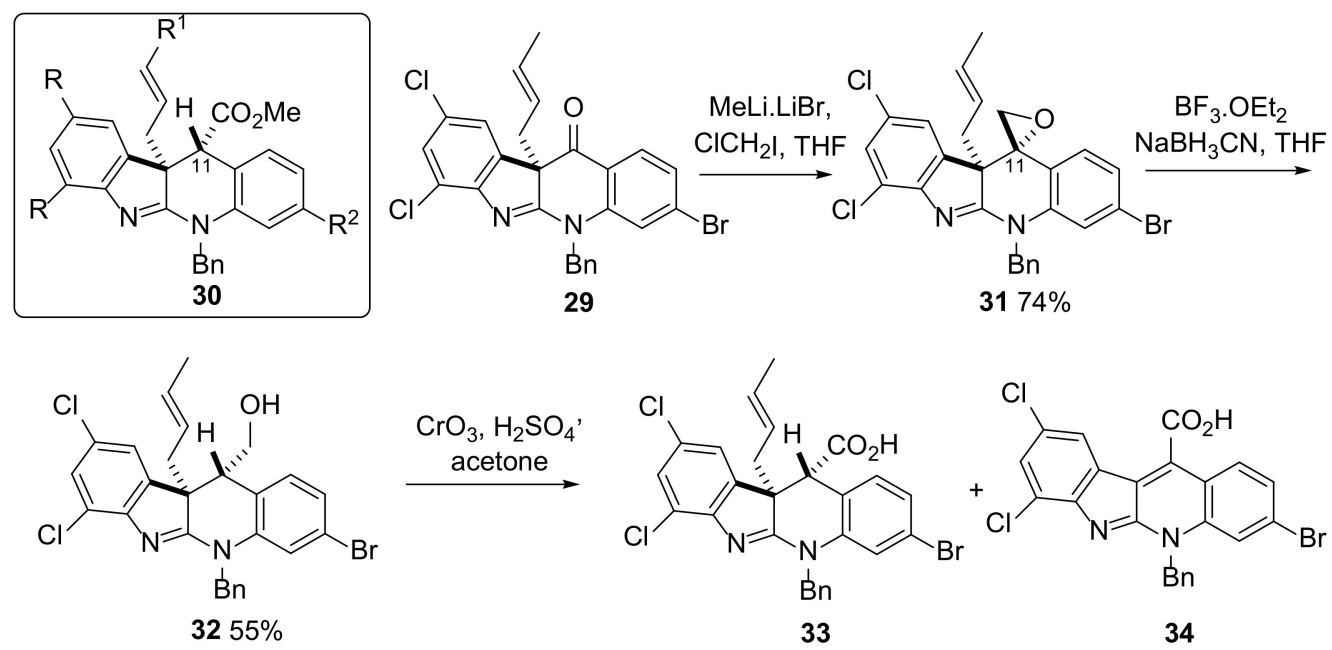

Scheme 7. Attempted formation of ester $30\left(R=C l, R^{1}=M e, R^{2}=B r\right)$ to enable ester alkylation as a method of incorporating the second all-carbon quaternary center. Reaction of $\mathbf{3 2}$ under Jones oxidation conditions gave $\mathbf{3 4}$ rather than the desired $\mathbf{3 3 .}$

A

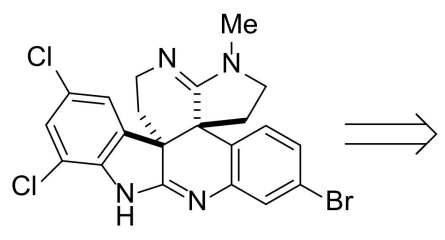

B<smiles>C=CC[C@]12C(=O)c3ccc(Br)cc3N(Cc3ccccc3)C1=Nc1c(Cl)cc(Cl)cc12</smiles>

27<smiles></smiles>

36<smiles>C=CCC1(CC=C)c2ccc(Br)cc2N(Cc2ccccc2)C2=Nc3c(Cl)cc(Cl)cc3[C@]21CC=C</smiles>

35

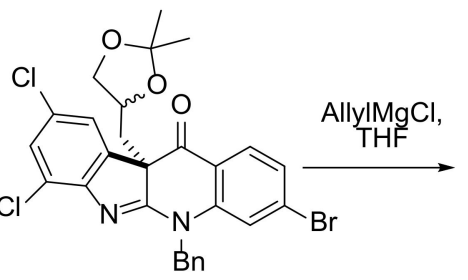

37a/37b $65 \%$ (over 2 steps)<smiles>C=CC[C@]1(O)c2ccc(Br)cc2N(Cc2ccccc2)C2=Nc3c(Cl)cc(Cl)cc3[C@]21C1COC(C)(C)O1</smiles>

38a/38b 90\%

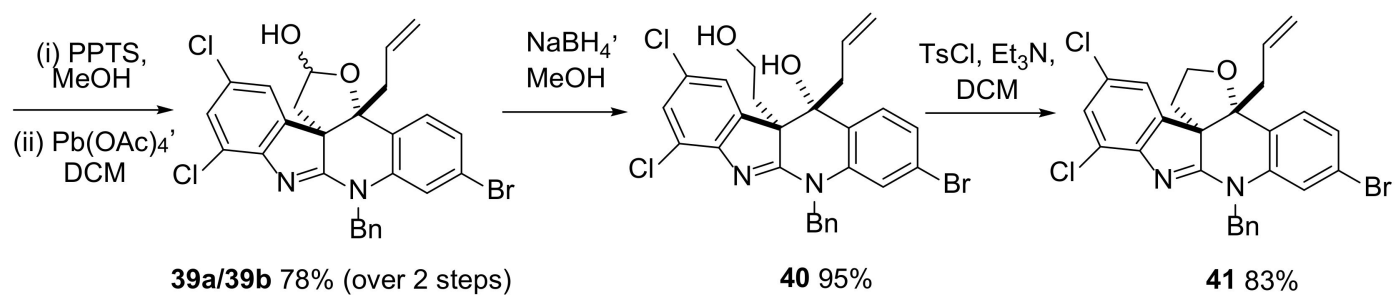

Scheme 8. A. One possible approach to perophoramidine 1 via diallyl-containing compound 35. Differentiation between the two allyl groups in 35 could potentially be achieved through an iodoetherification protocol. B. Synthesis of cyclic ether 41, a precursor to 35. PPTS = pyridinium p-toluenesulfonate, $\mathrm{TsCl}=$ p-toluenesulfonyl chloride.

After dihydroxylation of the allyl group in 27, the corresponding diastereomeric acetonides $37 \mathbf{a} / 37 \mathbf{b}$ (1:1 mixture) were formed in $65 \%$ yield over the two steps. Reaction of $37 \mathbf{a} / 37 \mathbf{b}$ with allylmagnesium chloride proceeded in high yield to give only two of the possible diastereomers (assigned structures as shown in $\mathbf{3 8 a / 3 8 b}$ based on expected stereochemical outcome of addition to the ketone). Deprotection of the acetonide group in 38a/38b was achieved under relatively mild conditions using PPTS in methanol [45] and the resulting crude reaction mixture was treated with lead tetraacetate, leading to 
lactols 39a/39b still as a 1:1 mixture of diastereomers. Reduction of $39 a / 39 b$ with sodium borohydride in methanol gave $\mathbf{4 0}$ which could be converted to cyclic ether $\mathbf{4 1}$ in excellent yield over the two steps. Importantly, after dealing with a series of diastereomeric mixtures for several steps in this sequence, recrystallization of $\mathbf{4 1}$ by slow evaporation of a solution of 41 in ethyl acetate provided crystals suitable for small-molecule X-ray crystallography. From the data obtained, it was clear that the stereochemistry at the two stereogenic centers in 41 was as planned. This places the ether ring almost perpendicular to the tetracyclic core of 41, with the allyl substituent on the opposite face to the ether ring (Figure 2).
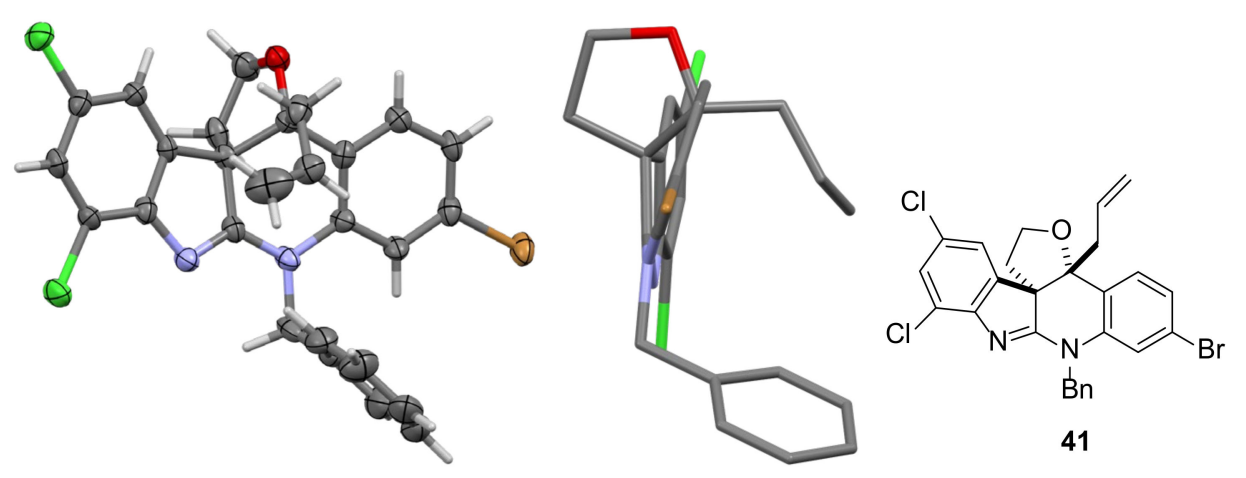

Figure 2. Two views of the X-ray crystal structure of $\mathbf{4 1}$ (ellipsoids drawn at the $50 \%$ probability level) used to confirm its structure.

Opening of the cyclic ether in $\mathbf{4 1}$ proceeded smoothly with 35 being obtained in $79 \%$ yield after reaction with $\mathrm{TiCl}_{4}$ and allyltrimethylsilane in $\mathrm{DCM}$ at $-78{ }^{\circ} \mathrm{C}$ for $4.5 \mathrm{~h}$. The presence of the halogen substituents in $\mathbf{3 5}$ had little effect on this robust reaction which has previously been reported to proceed in a similar manner with the non-halogenated analogue 42 to give 43 (87\% yield [44]). Previous attempts to differentiate between the two allyl groups present in 43 using an iodoetherification reaction resulted in the formation of 44 , the structural assignment of which (especially the relative stereochemistry) relied heavily on X-ray crystallographic analysis [44]. It was proposed that the presence of the chlorine substitutents in $\mathbf{3 5}$ may steer the outcome of this reaction away from that observed with $\mathbf{4 3}$ as a reduction in the electron density in the aryl ring due to the presence of the net deactivating chlorines would be expected to slow the proposed reaction of this ring with an intermediate iodonium ion central to the formation of 44 from 43 (Scheme 9 and Scheme S7).

Reaction of 35 with excess NIS in freshly base-washed $\mathrm{CDCl}_{3}$ was followed by purification of the crude reaction mixture by column chromatography using triethylamine treated silica. Mass spectrometric analysis of the product indicated that one iodine atom had been added to the molecule, possibly consistent with the desired formation of $\mathbf{3 6}$. However, detailed NMR analysis indicated that the structure of the major product from this reaction was not the planned iodoether 36 or an analogue of 44 . The characterization data obtained suggested that a major rearrangement of the molecule had taken place, leading to the formation of $\mathbf{4 5}$ (Scheme 9, Schemes S8-S10 and Figure S5 for a more detailed discussion of the data used in this assignment). In this case, it was not possible for us to prepare suitable quality crystals of 45 , emphasizing again how, in the absence of X-ray crystallographic analysis, certainty in structural assignment and especially stereochemistry can prove difficult in such complex systems (compound 45 is a single diastereomer but at present the relative stereochemistry at the centers marked * is unknown). 

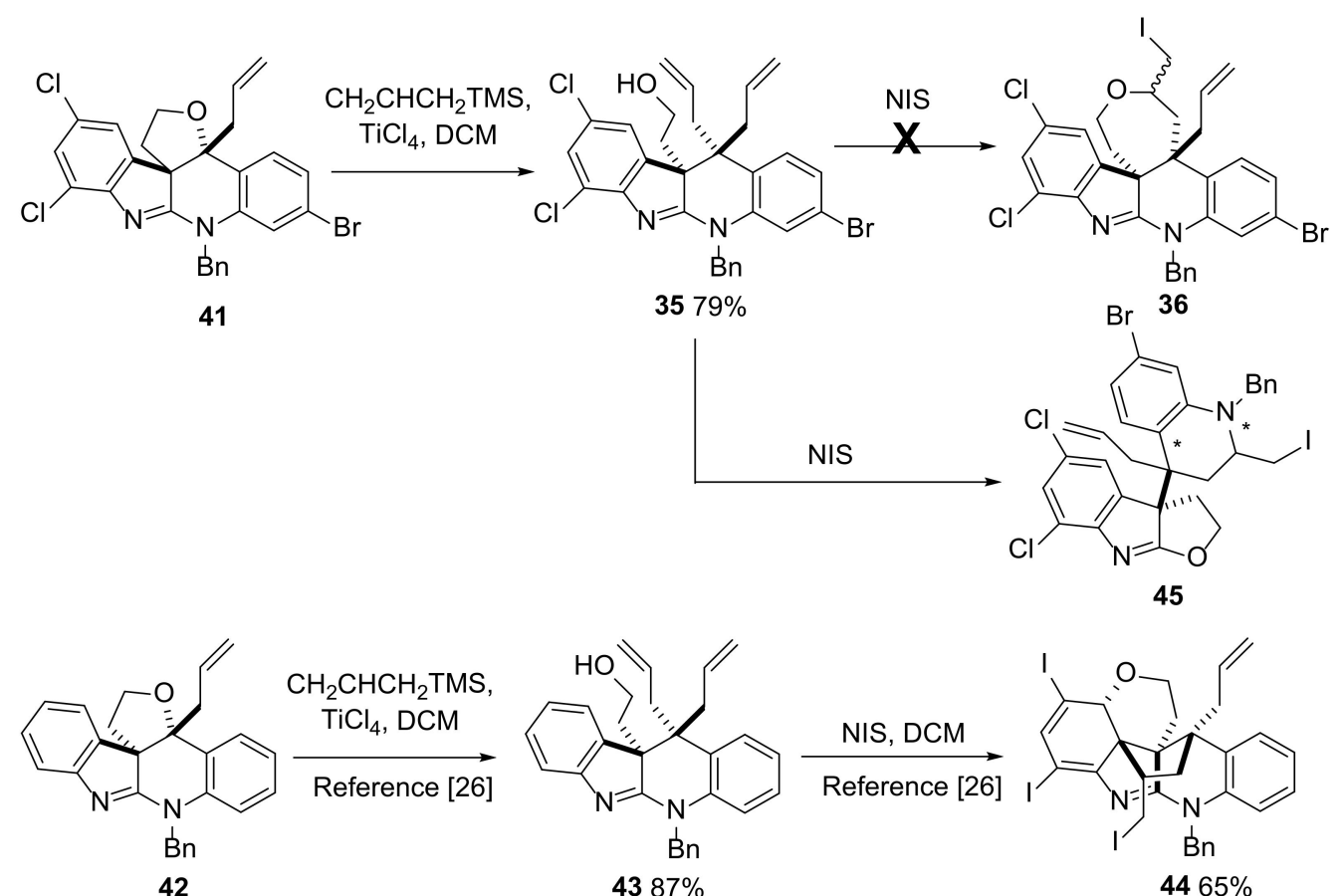

Scheme 9. Attempted conversion of 35 to 36 led instead to formation of 45 .

\section{Experimental}

\subsection{General Experimental Details}

Nuclear magnetic resonance (NMR) spectra were recorded on a Bruker Advance $300\left({ }^{1} \mathrm{H}, 300 ;{ }^{13} \mathrm{C}, 75 \mathrm{MHz}\right)$, Bruker Advance II $400\left({ }^{1} \mathrm{H}, 400 ;{ }^{13} \mathrm{C}, 101 \mathrm{MHz}\right)$ or Bruker Ascend $500\left({ }^{1} \mathrm{H} 500 ;{ }^{13} \mathrm{C} 126 \mathrm{MHz}\right) .{ }^{13} \mathrm{C}$ NMR spectra were recorded using the PENDANT pulse sequence. Peaks were assigned where possible with the aid of the two-dimensional NMR spectroscopic techniques COSY, HSQC, and HMBC. All NMR spectra were acquired using the deuterated solvent as the lock and the residual solvent as the internal reference. Melting points were recorded in open capillaries using an Electrothermal 9100 melting point apparatus. Values are quoted to the nearest $1^{\circ} \mathrm{C}$ and are uncorrected. Infrared spectra were recorded on a Perkin Elmer Paragon 1000 FT spectrometer. Absorption maxima are reported in wavenumbers $\left(\mathrm{cm}^{-1}\right)$. Mass spectra were recorded using either atmospheric pressure chemical ionization (APCI) or electrospray (ES) ionization methods in the positive or negative ionization mode by Mrs Caroline Horsburgh in the University of St Andrews School of Chemistry mass spectrometry service or via the EPSRC Mass Spectrometry Service Centre (Swansea, UK).

\subsection{X-ray Structure Determination for $\mathbf{2 7}$ and $\mathbf{4 1}$}

X-ray diffraction data for compounds 27 and $\mathbf{4 1}$ were collected at $93 \mathrm{~K}$ using a Rigaku MM007 High Brilliance RA generator/confocal optics and Mercury70 CCD system [Mo $\mathrm{K} \alpha$ radiation $(\lambda=0.71073 \AA)$ ]. Intensity data were collected using both $\omega$ and $\varphi$ steps accumulating area detector images spanning at least a hemisphere of reciprocal space. Data for all compounds analyzed were collected and processed (including correction for Lorentz, polarization and absorption) using CrystalClear [46]. Structures were solved by Patterson methods (PATTY [47]) and refined by full-matrix least-squares against $\mathrm{F}^{2}$ (SHELXL-2018/3 [48]). Non-hydrogen atoms were refined anisotropically, and hydrogen atoms were refined using a riding model. All calculations were performed using the CrystalStructure [49] interface. Selected crystallographic data are presented in Table S3. Deposition numbers 2109434 and 2109435 contain the supplementary crystallographic data for this paper. These data are provided free of charge by the joint Cambridge Crystallo- 
graphic Data Center and Fachinformationszentrum Karlsruhe Access Structures service www.ccdc.cam.ac.uk/structures.

\subsection{Preparation of Selected Compounds}

\subsubsection{N-Boc-5,7-dichloroindole-3-carbaldehyde $\mathbf{1 6}$}

To a suspension of $\mathbf{1 5}(5.00 \mathrm{~g}, 23.36 \mathrm{mmol})$ and $\mathrm{Boc}_{2} \mathrm{O}(5.61 \mathrm{~g}, 25.69 \mathrm{mmol})$ in DCM $(100 \mathrm{~mL})$ was added DMAP $(0.342 \mathrm{~g}, 2.80 \mathrm{mmol})$. After stirring for $15 \mathrm{~min}$, a saturated solution of $\mathrm{NaHCO}_{3}$ (aq.) (100 mL) was added and the reaction mixture extracted with $\mathrm{DCM}(2 \times 50 \mathrm{~mL})$. The organic phase was washed with $0.5 \mathrm{M} \mathrm{HCl}$ (aq.) $(100 \mathrm{~mL})$ before being dried $\left(\mathrm{MgSO}_{4}\right)$, filtered and the solvent removed under reduced pressure to give 16 as a pale yellow solid that required no further purification $(6.93 \mathrm{~g}, 94 \%)$. m.p. $102-103{ }^{\circ} \mathrm{C}$; I.R. $(\mathrm{KBr}) v_{\max } 2924,1723,1601,1465,1453,1253,735 \mathrm{~cm}^{-1} ;{ }^{1} \mathrm{H}$ NMR $\left(400 \mathrm{MHz}, \mathrm{CDCl}_{3}\right) \delta$ 10.07 (s, 1H, CHO), 8.30 (d, J = 2.0 Hz, 1H, C4-H), 8.20 (s, 1H, C2-H), 7.46 (d, J = 2.0 Hz, 1H, C6-H), $1.71\left(\mathrm{~s}, 9 \mathrm{H},\left(\mathrm{CH}_{3}\right)_{3}\right) ;{ }^{13} \mathrm{C} \mathrm{NMR}\left(100 \mathrm{MHz}, \mathrm{CDCl}_{3}\right) 184.8(\mathrm{CHO}), 147.5\left(\mathrm{CO}_{2}{ }^{t} \mathrm{Bu}\right)$, 140.0 (C2), 131.3 (C7a), 130.9 (C3a), 129.9 (C5), 128.0 (C6), 120.7 (C7), 120.6 (C4), 120.2 (C3), $86.9\left(\mathrm{C}\left(\mathrm{CH}_{3}\right)_{3}\right), 27.8\left(\mathrm{C}\left(\mathrm{CH}_{3}\right)_{3}\right)$; HR MS [ES $\left.{ }^{+}\right]: m / z$ calcd. for $\mathrm{C}_{14} \mathrm{H}_{13}{ }^{35} \mathrm{Cl}_{2} \mathrm{NO}_{3} \mathrm{Na} 336.0170$, found $336.0164[\mathrm{M}+\mathrm{Na}]^{+}$.

\subsection{2. tert-Butyl}

3-((4-bromo-2-nitrophenyl)(hydroxy)methyl)-5,7-dichloro-1H-indole-1-carboxylate 19

To a solution of $17(5.16 \mathrm{~g}, 15.70 \mathrm{mmol})$ in THF $(23 \mathrm{~mL})$ at $-40{ }^{\circ} \mathrm{C}$ was added $2 \mathrm{M}$ solution of phenylmagnesium chloride in THF $(8.40 \mathrm{~mL}, 16.80 \mathrm{mmol})$, followed $15 \mathrm{~min}$ later by a solution of 16 (3.30 g, $10.50 \mathrm{mmol})$ in THF $(23 \mathrm{~mL})$. The mixture was stirred for $1 \mathrm{~h}$ at $-40{ }^{\circ} \mathrm{C}$ before being allowed to warm to room temperature for a further $1 \mathrm{~h}$. A saturated solution of $\mathrm{NH}_{4} \mathrm{Cl}$ (aq.) $(50 \mathrm{~mL})$ was then added followed by water $(75 \mathrm{~mL})$ and ethyl acetate $(75 \mathrm{~mL})$. The mixture was separated and the organic phase washed with a saturated solution of $\mathrm{NaCl}$ (aq.) $(50 \mathrm{~mL})$, dried $\left(\mathrm{MgSO}_{4}\right)$ and the solvent removed under reduced pressure. The crude product was purified by column chromatography (10-20\% EtOAc/hexanes), giving 19 as a yellow solid (5.21 g, 96\%). m.p. 56-58 ${ }^{\circ} \mathrm{C}$; I.R. (KBr) $v_{\max }$ 3386, 1737, 1531, 1346, $1150 \mathrm{~cm}^{-1} ;{ }^{1} \mathrm{H}$ NMR $\left(400 \mathrm{MHz}, \mathrm{CDCl}_{3}\right) \delta 8.08(\mathrm{~d}, J=2.0 \mathrm{~Hz}, 1 \mathrm{H}$, $\left.\mathrm{C}^{\prime}-\mathrm{H}\right), 7.70\left(\mathrm{dd}, J=8.4,2.0 \mathrm{~Hz}, 1 \mathrm{H}, \mathrm{C} 5^{\prime}-\mathrm{H}\right), 7.57\left(\mathrm{~d}, J=8.4 \mathrm{~Hz}, 1 \mathrm{H}, \mathrm{C} 6^{\prime}-\mathrm{H}\right), 7.30(\mathrm{~s}, 1 \mathrm{H}$, C2-H), 7.29 (d, J = 1.9 Hz, 1H, ArC-H), $7.26(\mathrm{~d}, J=1.9 \mathrm{~Hz}, 1 \mathrm{H}, \mathrm{ArC}-\mathrm{H}), 6.50(\mathrm{~d}, J=4.4$ $\mathrm{Hz}, 1 \mathrm{H}, \mathrm{CHOH}), 2.84(\mathrm{~d}, J=4.4 \mathrm{~Hz}, 1 \mathrm{H}, \mathrm{OH}), 1.56\left(\mathrm{~s}, 9 \mathrm{H},\left(\mathrm{CH}_{3}\right)_{3}\right) ;{ }^{13} \mathrm{C} \mathrm{NMR}(100 \mathrm{MHz}$, $\left.\mathrm{CDCl}_{3}\right) \delta 148.5\left(\mathrm{CO}_{2}{ }^{t} \mathrm{Bu}\right), 148.3\left(\mathrm{C}^{\prime}\right), 136.8\left(\mathrm{C}^{\prime}\right), 135.8\left(\mathrm{C}^{\prime}\right), 132.2(\mathrm{ArC}), 131.3(\mathrm{ArC}), 130.6$ $\left(\mathrm{C}^{\prime}\right), 129.0$ (ArC), 128.8 (C2), $128.0\left(\mathrm{C}^{\prime}\right), 126.8$ (ArC), 122.4 (C4'), 121.2 (ArC), 119.9 (ArC), $118.1(\mathrm{ArC}), 85.5\left(\underline{\mathrm{C}}\left(\mathrm{CH}_{3}\right)_{3}\right), 65.0(\mathrm{CHOH}), 27.8\left(\mathrm{C}_{\left.\left(\mathrm{CH}_{3}\right)_{3}\right)}\right.$; HR MS [APCI $]$ : $\mathrm{m} / z$ calcd. for $\mathrm{C}_{20} \mathrm{H}_{17}{ }^{79} \mathrm{Br}^{35} \mathrm{Cl}_{2} \mathrm{~N}_{2} \mathrm{O}_{5} \mathrm{NH}_{4}$ 532.0036, found $532.0034\left[\mathrm{M}+\mathrm{NH}_{4}\right]^{+}$.

\subsection{3. tert-Butyl 3-(4-bromo-2-nitrobenzoyl)-5,7-dichloro- $1 H$-indole-1-carboxylate 20}

To a solution of $19(3.25 \mathrm{~g}, 6.30 \mathrm{mmol})$ and $N$-methylmorpholine- $N$-oxide $(1.48 \mathrm{~g}$, $12.60 \mathrm{mmol})$ in DCM $(35 \mathrm{~mL})$ in the presence of $3 \AA$ molecular sieves at $0{ }^{\circ} \mathrm{C}$ was added tetrapropylammonium perruthenate $(0.110 \mathrm{~g}, 0.310 \mathrm{mmol})$. The mixture was stirred for $30 \mathrm{~min}$ at $0{ }^{\circ} \mathrm{C}$ followed by a further $6 \mathrm{~h}$ at room temperature before the mixture was filtered and the solvent removed under reduced pressure. The crude product was purified by column chromatography (5-25\% EtOAc/hexanes), giving 20 as a white solid (2.31 g, 71\%). m.p. 126-127 ${ }^{\circ}$ C; I.R. (KBr) $v_{\max } 2924,1745,1654,1544,1348 \mathrm{~cm}^{-1} ;{ }^{1} \mathrm{H}$ NMR $(400 \mathrm{MHz}$, $\left.\mathrm{CDCl}_{3}\right) \delta 8.42(\mathrm{~d}, J=1.9 \mathrm{~Hz}, 1 \mathrm{H}, \mathrm{C} 4-\mathrm{H}), 8.39\left(\mathrm{~d}, J=1.8 \mathrm{~Hz}, 1 \mathrm{H}, \mathrm{C}^{\prime}-\mathrm{H}\right), 7.95(\mathrm{dd}, J=8.1$, $\left.1.9 \mathrm{~Hz}, 1 \mathrm{H}, \mathrm{C} 5^{\prime}-\mathrm{H}\right), 7.64(\mathrm{~s}, 1 \mathrm{H}, \mathrm{C} 2-\mathrm{H}), 7.48(\mathrm{~d}, J=2 \mathrm{~Hz}, 1 \mathrm{H}, \mathrm{C} 6-\mathrm{H}), 7.47$ (d, J = 8.1 Hz, 1H, $\left.\mathrm{C}^{\prime}-\mathrm{H}\right), 1.66\left(\mathrm{~s}, 9 \mathrm{H}, \mathrm{C}\left(\mathrm{CH}_{3}\right)_{3}\right) ;{ }^{13} \mathrm{C} \mathrm{NMR}\left(100 \mathrm{MHz}, \mathrm{CDCl}_{3}\right) \delta 186.2(\mathrm{C}=\mathrm{O}), 147.9\left(\mathrm{CO}_{2}{ }^{t} \mathrm{Bu}\right)$, $147.3\left(\mathrm{C} 2^{\prime}\right), 137.5(\mathrm{C} 2), 137.0\left(\mathrm{C}^{\prime}\right), 134.5\left(\mathrm{C}^{\prime}\right), 131.1$ (C7a), 131.1 (ArC), 130.9 (ArC), 130.0 $\left(\mathrm{C}^{\prime}\right), 128.0(\mathrm{C} 6), 128.0\left(\mathrm{C}^{\prime}\right), 124.5\left(\mathrm{C}^{\prime}\right), 121.1(\mathrm{C} 4), 120.7(\mathrm{ArC}), 118.6(\mathrm{C} 3 \mathrm{a}), 87.5\left(\mathrm{C}\left(\mathrm{CH}_{3}\right)_{3}\right)$, $27.7\left(\mathrm{C}\left(\mathrm{CH}_{3}\right)_{3}\right)$; HR MS [ES ${ }^{+}$]: $m / z$ calcd. for $\mathrm{C}_{20} \mathrm{H}_{15}{ }^{79} \mathrm{Br}^{35} \mathrm{Cl}_{2} \mathrm{~N}_{2} \mathrm{O}_{5} 534.9439$, found 534.9432 $[\mathrm{M}+\mathrm{H}]^{+}$.This was prepared as in 3.3.1. using benzotriazole $(14.69 \mathrm{~g}, 123.3 \mathrm{mmol})$, thionyl chloride (3.67 g, $2.24 \mathrm{~mL}, 30.8 \mathrm{mmol})$ and (E)-3-(2-methylphenyl)prop-2-enoic acid (5.00 g, 
$30.8 \mathrm{mmol})$. Drying and evaporation followed by recrystallization of the residue $\left(\mathrm{CH}_{2} \mathrm{Cl}_{2}\right)$ gave $33(1.77 \mathrm{~g}, 22 \%)$ as a white powder, m.p. $124-125^{\circ} \mathrm{C}$ (Lit. [21] 127-129 $\left.{ }^{\circ} \mathrm{C}\right) ; \delta_{\mathrm{H}} 8.47(1$ $\mathrm{H}, \mathrm{d}, J 15, \mathrm{COCH}=\mathrm{CH}), 8.42(1 \mathrm{H}, \mathrm{dt}, J$ 8, 1, H-4 or $7 \mathrm{of} \mathrm{Bt}), 8.16(1 \mathrm{H}, \mathrm{dt}, J 8,1, \mathrm{H}-4$ or 7 of $\mathrm{Bt}), 8.07(1 \mathrm{H}, \mathrm{d}, J 15, \mathrm{COCH}=\mathrm{CH}), 7.86(1 \mathrm{H}, \mathrm{d}, J$ 8), $7.69(1 \mathrm{H}, \mathrm{ddd}, J 8,7,1, \mathrm{H}-5$ or $6 \mathrm{of} \mathrm{Bt})$, $7.54(1 \mathrm{H}, \mathrm{ddd}, \mathrm{J} 8,7,1, \mathrm{H}-5$ or 6 of Bt), 7.40-7.27 (3 H, m) and $2.56(3 \mathrm{H}, \mathrm{s}, \mathrm{Me})$.

\subsection{4. (2-Amino-4-bromophenyl)(5,7-dichloro-1H-indol-3-yl)methanone 21}

To a solution of $22(800 \mathrm{mg}, 1.85 \mathrm{mmol})$ in DCM $(9 \mathrm{~mL})$ was added trifluoroacetic acid $(3 \mathrm{~mL})$ and the solution was stirred at room temperature for $18 \mathrm{~h}$. The solvent was removed under reduced pressure before a saturated solution of $\mathrm{NaHCO}_{3}$ (aq.) (20 mL) was added and the mixture extracted with DCM $(3 \times 20 \mathrm{~mL})$. The organic extracts were dried $\left(\mathrm{MgSO}_{4}\right)$, filtered and the solvent removed under reduced pressure to give $\mathbf{2 1}$ as an orange solid (673 mg, 94\%) that required no further purification. m.p. 191-193 ${ }^{\circ} \mathrm{C}$; I.R. (KBr) $v_{\max }$ 3446, 3346, 1691, 1597, 1428, $1189 \mathrm{~cm}^{-1} ;{ }^{1} \mathrm{H}$ NMR (400 MHz, d $\mathrm{d}^{6}$-DMSO) $\delta 12.65$ (s, 1H, NH), $8.09(\mathrm{~d}, J=1.9 \mathrm{~Hz}, 1 \mathrm{H}, \mathrm{C} 4-\mathrm{H}), 7.94(\mathrm{~d}, J=3.1 \mathrm{~Hz}, 1 \mathrm{H}, \mathrm{C} 2-\mathrm{H}), 7.53\left(\mathrm{~d}, J=8.4 \mathrm{~Hz}, 1 \mathrm{H}, \mathrm{C} 6^{\prime}-\mathrm{H}\right)$, $7.46(\mathrm{~d}, J=1.8 \mathrm{~Hz}, 1 \mathrm{H}, \mathrm{C} 6-\mathrm{H}), 7.03\left(\mathrm{~d}, J=1.9 \mathrm{~Hz}, 1 \mathrm{H}, \mathrm{C}^{\prime}-\mathrm{H}\right), 6.73(\mathrm{dd}, J=8.4,1.9 \mathrm{~Hz}, 1 \mathrm{H}$, C5'-H), 6.64 (br. s, 2H, NH $)$; ${ }^{13} \mathrm{C}$ NMR (100 MHz, d ${ }^{6}$-DMSO) $\delta 190.3(\mathrm{C}=\mathrm{O}), 151.0\left(\mathrm{C}^{\prime}\right)$, 136.0 (C2), 133.5 (C6'), 132.6 (C7a), 129.2 (C3a), 126.7 (C5), 126.6 (C3), 126.3 (C4'), 122.2 (C6), 119.6 (C4), $119.1\left(\mathrm{C}^{\prime}\right), 118.5\left(\mathrm{C}^{\prime}\right), 117.6\left(\mathrm{C}^{\prime}\right) 116.8(\mathrm{C} 7)$; HR MS (ES $\left.{ }^{-}\right) \mathrm{m} / z$ calcd. for $\mathrm{C}_{15} \mathrm{H}_{8}{ }^{79} \mathrm{Br}^{35} \mathrm{Cl}_{2} \mathrm{~N}_{2} \mathrm{O} 380.9197$, found $380.9192[\mathrm{M}-\mathrm{H}]^{-}$.

\subsection{5. tert-Butyl 3-(2-amino-4-bromobenzoyl)-5,7-dichloro-1H-indole-1-carboxylate 22}

A suspension of $20(1.00 \mathrm{~g}, 1.945 \mathrm{mmol})$ and iron powder $(0.543 \mathrm{~g}, 9.725 \mathrm{mmol})$ in acetic acid $(10 \mathrm{~mL})$ and ethanol $(10 \mathrm{~mL})$ was stirred for $18 \mathrm{~h}$ at room temperature. The mixture was filtered through a plug of Celite. The celite was washed with DCM (50 mL) and combined with the existing filtrate. Water $(50 \mathrm{~mL})$ was added. The mixture was partitioned and the aqueous layer further extracted with DCM $(2 \times 25 \mathrm{~mL})$. The combined organic layers were concentrated under reduced pressure before being re-dissolved in $\operatorname{DCM}(50 \mathrm{~mL})$, washed with a saturated solution of $\mathrm{NaHCO}_{3}$ (aq.) $(100 \mathrm{~mL})$, dried $\left(\mathrm{MgSO}_{4}\right)$, filtered and the solvent removed under reduced pressure. The crude product was purified by column chromatography (10-25\% EtOAc/hexanes) to give 22 as a yellow solid (0.876 g, 93\%). m.p. 143-144 ${ }^{\circ}$ C; I.R. (KBr) $v_{\max } 3442,3336,1735,1645,1605 \mathrm{~cm}^{-1}$; ${ }^{1} \mathrm{H}$ NMR

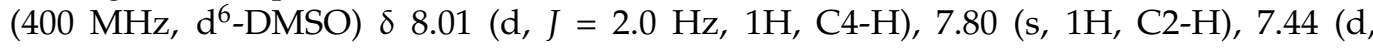
$\left.J=8.5 \mathrm{~Hz}, 1 \mathrm{H}, \mathrm{C} 6^{\prime}-\mathrm{H}\right), 7.35(\mathrm{~d}, J=1.9 \mathrm{~Hz}, 1 \mathrm{H}, \mathrm{C} 6-\mathrm{H}), 6.87\left(\mathrm{~d}, J=1.8 \mathrm{~Hz}, 1 \mathrm{H}, \mathrm{C} 3^{\prime}-\mathrm{H}\right)$, $6.75\left(\mathrm{dd}, J=8.4,1.9 \mathrm{~Hz}, 1 \mathrm{H}, \mathrm{C}^{\prime}-\mathrm{H}\right), 5.87$ (br. s, $\left.2 \mathrm{H}, \mathrm{NH}_{2}\right), 1.58\left(\mathrm{~s}, 9 \mathrm{H}, \mathrm{C}\left(\mathrm{CH}_{3}\right)_{3}\right) ;{ }^{13} \mathrm{C} \mathrm{NMR}$ $\left(100 \mathrm{MHz}, \mathrm{d}^{6}\right.$-DMSO) $\delta 190.8(\mathrm{C}=\mathrm{O}), 150.9\left(\mathrm{C}^{\prime}\right), 147.0\left(\mathrm{CO}_{2}{ }^{t} \mathrm{Bu}\right), 135.7(\mathrm{C} 2), 133.7\left(\mathrm{C}^{\prime}\right)$, 132.4 (C7a), $130.3(\mathrm{C}), 130.0(\mathrm{C}), 128.9\left(\mathrm{C}^{\prime}\right), 127.4(\mathrm{C} 6), 120.8(\mathrm{C}), 120.6(\mathrm{C} 4), 119.5\left(\mathrm{C}^{\prime}\right)$,

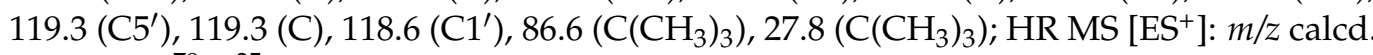
for $\mathrm{C}_{20} \mathrm{H}_{17}{ }^{79} \mathrm{Br}^{35} \mathrm{Cl}_{2} \mathrm{~N}_{2} \mathrm{O}_{3} \mathrm{Na} 504.9697$, found $504.9693[\mathrm{M}+\mathrm{Na}]^{+}$.

\subsection{6. (2-Benzylamino)-4-bromophenyl)(5,7-dichloro-1H-indol-3-yl)methanone 9}

To a solution of $22(1.00 \mathrm{~g}, 2.07 \mathrm{mmol})$ in TFA $(8 \mathrm{~mL})$ was added sodium triacetoxyborohydride $(0.875 \mathrm{~g}, 4.13 \mathrm{mmol})$. After $5 \mathrm{~min}$, a solution of benzaldehyde $(0.219 \mathrm{~g}$, $2.07 \mathrm{mmol})$ in DCM $(8 \mathrm{~mL})$ was added dropwise and the solution was stirred for $1 \mathrm{~h}$ at room temperature. A second aliquot of sodium triacetoxyborohydride $(0.875 \mathrm{~g}, 4.13$ $\mathrm{mmol})$ in TFA ( $4 \mathrm{~mL})$ was added and the mixture was stirred for a further $1 \mathrm{~h}$ at room temperature. The mixture was then poured into an ice cold saturated solution of $\mathrm{NaHCO}_{3}$ (aq.) $(20 \mathrm{~mL})$ and extracted with DCM $(3 \times 10 \mathrm{~mL})$. The combined organic extracts were dried $\left(\mathrm{MgSO}_{4}\right)$, filtered and the solvent removed under reduced pressure before the crude product was purified by column chromatography (5-30\% EtOAc/hexanes), giving 22 as an orange-yellow solid (0.558 g, 68\%). m.p. 81-82 ${ }^{\circ} \mathrm{C}$; I.R. (KBr) $v_{\max } 1691$ (C=O), 1602, 1419, $1185 \mathrm{~cm}^{-1}$; ${ }^{1} \mathrm{H}$ NMR $\left(400 \mathrm{MHz}, \mathrm{CDCl}_{3}\right) \delta 8.81$ (br. s, $\left.1 \mathrm{H}, \mathrm{NH}\right), 8.28$ (br. t, $J=5.3 \mathrm{~Hz}, 1 \mathrm{H}$, NHBn), 8.05 (d, J = 1.5 Hz, 1H, C4-H), $7.54(\mathrm{~d}, J=2.9 \mathrm{~Hz}, 1 \mathrm{H}, \mathrm{C} 2-\mathrm{H}), 7.48$ (d, J = 8.4 Hz, $\left.1 \mathrm{H}, \mathrm{C6}^{\prime}-\mathrm{H}\right), 7.30-7.19(\mathrm{~m}, 6 \mathrm{H}, \mathrm{C} 6-\mathrm{H}$ and $5 \times \mathrm{ArC}-\mathrm{H}), 6.83\left(\mathrm{~d}, J=1.8 \mathrm{~Hz}, 1 \mathrm{H}, \mathrm{C}^{\prime}-\mathrm{H}\right), 6.68$ 
$\left(\mathrm{dd}, J=8.4,1.9 \mathrm{~Hz}, 1 \mathrm{H}, \mathrm{C}^{\prime}-\mathrm{H}\right), 4.34\left(\mathrm{~d}, J=5.5 \mathrm{~Hz}, 2 \mathrm{H}, \mathrm{CH}_{2}\right) ;{ }^{13} \mathrm{C} \mathrm{NMR}\left(100 \mathrm{MHz}, \mathrm{CDCl}_{3}\right) \delta$ 191.6 (C=O), $151.0\left(\mathrm{C}^{\prime}\right), 137.9$ (ArC), $134.1\left(\mathrm{C}^{\prime}\right), 132.6(\mathrm{C} 2), 132.1(\mathrm{C} 7 \mathrm{a}), 129.2\left(\mathrm{C}^{\prime}\right), 128.8$ $(\mathrm{ArCH}), 128.4(\mathrm{C} 3 \mathrm{a}), 128.3(\mathrm{C} 3), 127.5(\mathrm{ArCH}), 127.3(\mathrm{ArCH}), 123.5(\mathrm{C} 6), 120.5(\mathrm{C} 4), 118.9$ (ArC), $118.5\left(\mathrm{C}^{\prime}\right), 117.8\left(\mathrm{C}^{\prime}\right), 117.3(\mathrm{C}), 114.7\left(\mathrm{C}^{\prime}\right), 47.2\left(\mathrm{CH}_{2}\right)$; HR MS [ES $\left.{ }^{-}\right]: m / z$ calcd. for $\mathrm{C}_{22} \mathrm{H}_{14}{ }^{79} \mathrm{Br}^{35} \mathrm{Cl}_{2} \mathrm{~N}_{2} \mathrm{O} 470.9667$, found $470.9673[\mathrm{M}-\mathrm{H}]^{-} .21$ was also obtained as an orange solid $(0.151 \mathrm{~g}, 19 \%)$.

\subsubsection{5-Benzyl-3-bromo-7,9-dichloro-5H-indolo[2,3-b]quinolin-11(6H)-one 3}

To a solution of 9 (250 mg, $0.527 \mathrm{mmol})$ in $\mathrm{MeCN}(6 \mathrm{~mL})$ was added $N$-chlorosuccinimide (169 $\mathrm{mg}, 1.265 \mathrm{mmol})$ and $\mathrm{Et}_{3} \mathrm{~N}(176 \mu \mathrm{L}, 1.265 \mathrm{mmol})$. The mixture was stirred for $24 \mathrm{~h}$ at room temperature before the precipitate was collected by filtration, giving 3 as a cream-colored solid (137 mg, 55\%). m.p. $>320{ }^{\circ} \mathrm{C}$ (dec.); I.R. (KBr) $v_{\max } 1706,1603,1536$, $1181 \mathrm{~cm}^{-1} ;{ }^{1} \mathrm{H}$ NMR (400 MHz, d6-DMSO) $\delta 12.45$ (br. s, $\left.1 \mathrm{H}, \mathrm{NH}\right), 8.27$ (d, $J=8.5 \mathrm{~Hz}, 1 \mathrm{H}$, $\mathrm{C} 1-\mathrm{H}), 8.14(\mathrm{~d}, J=1.9 \mathrm{~Hz}, 1 \mathrm{H}, \mathrm{C} 10-\mathrm{H}), 7.78(\mathrm{~d}, J=1.6 \mathrm{~Hz}, 1 \mathrm{H}, \mathrm{C} 4-\mathrm{H}), 7.54(\mathrm{dd}, J=8.5,1.6 \mathrm{~Hz}$, $1 \mathrm{H}, \mathrm{C} 2-\mathrm{H}), 7.46$ (d, J = 1.9 Hz, 1H, C8-H), 7.36-7.26 (m, 3H, 3 x ArC-H), 7.18-7.16 (m, 2H, $2 \times \mathrm{ArC}-\mathrm{H}), 5.98\left(\mathrm{~s}, 2 \mathrm{H}, \mathrm{CH}_{2}\right) ;{ }^{13} \mathrm{C}$ NMR $(100 \mathrm{MHz}, \mathrm{d} 6-\mathrm{DMSO}) \delta 171.4(\mathrm{C}=\mathrm{O}), 148.0(\mathrm{C} 5 \mathrm{a})$, 139.6 (C4a), 135.6 (ArC), 130.6 (C6a), 129.0 (ArCH), $127.9(\mathrm{C} 1), 127.5(\mathrm{ArCH}), 126.5(\mathrm{ArC})$, 126.3 (ArC), 126.0 (ArCH), 125.6 (C2), 125.5 (C3), 123.8 (C11a), 122.4 (C8), 118.8 (C4), 118.0 (C10), 116.2 (ArC), $49.0\left(\mathrm{CH}_{2}\right)$; HR MS [ES ${ }^{+}$: $m / z$ calcd. for $\mathrm{C}_{22} \mathrm{H}_{14}{ }^{35} \mathrm{Cl}_{2}{ }^{81} \mathrm{BrN}_{2} \mathrm{O} 470.9661$, found $470.9659[\mathrm{M}+\mathrm{H}]^{+}$.

\subsubsection{5-Benzyl-3-bromo-7,9,11-trichloro-5H-indolo[2,3-b]quinoline 25}

A solution of $3(1.50 \mathrm{~g}, 3.18 \mathrm{mmol})$ in $\mathrm{POCl}_{3}(15 \mathrm{~mL})$ was heated to reflux for $1 \mathrm{~h}$ before removing the solvent under reduced pressure. DCM $(100 \mathrm{~mL})$ and a saturated solution of $\mathrm{NaHCO}_{3}$ (aq.) (250 mL) were added and the mixture partitioned before the organic layer was dried $\left(\mathrm{MgSO}_{4}\right)$, filtered and concentrated to give 25 in sufficient purity without further purification $(1.54 \mathrm{~g}, 99 \%)$. m.p. $260-263{ }^{\circ} \mathrm{C}$; I.R. (KBr) $v_{\max } 1705,1602,1484,1175$, $847 \mathrm{~cm}^{-1} ;{ }^{1} \mathrm{H}$ NMR $\left(400 \mathrm{MHz}, \mathrm{CDCl}_{3}\right) \delta 8.31(\mathrm{~d}, J=2.0 \mathrm{~Hz}, 1 \mathrm{H}, \mathrm{C} 10-\mathrm{H}), 8.28(\mathrm{~d}, J=8.8 \mathrm{~Hz}$, $1 \mathrm{H}, \mathrm{C} 1-\mathrm{H}), 7.87$ (d, J = 1.7 Hz, 1H, C4-H), 7.59 (d, J = 1.7 Hz, 1H, C2-H), 7.58 (d, J = 2.0 Hz, 1H, C8-H), 7.36-7.27 (m, 5H, $5 \times \mathrm{Ar}-\mathrm{H}), 6.20\left(\mathrm{~s}, 2 \mathrm{H}, \mathrm{CH}_{2}\right) ;{ }^{13} \mathrm{C} \mathrm{NMR}\left(101 \mathrm{MHz}^{\mathrm{C}} \mathrm{CDCl}_{3}\right) \delta$ 155.4 (C5a), 150.3 (C6a), 137.2 (ArC), 134.8 (ArC), 129.3 (C8), 129.1 (ArCH), 128.1 (ArCH), 127.7 (C1), 127.0 (ArCH), 126.9 (ArC), 126.3 (C2), 125.9 (ArC), 125.6 (ArC), $124.4(\mathrm{ArC})$, 123.2 (ArC), 122.0 (C10), 118.5 (C4), 118.3 (ArC), $50.0\left(\mathrm{CH}_{2}\right)$; HR MS (ES $\left.{ }^{+}\right) \mathrm{m} / z$ calcd. for $\mathrm{C}_{22} \mathrm{H}_{12} \mathrm{~N}_{2}{ }^{35} \mathrm{Cl}_{3}{ }^{81} \mathrm{BrNa}$ 512.9127, found $512.9130[\mathrm{M}+\mathrm{Na}]^{+}$.

\subsubsection{1-(Allyloxy)-5-benzyl-3-bromo-7,9-dichloro-5H-indolo[2,3-b]quinoline 26}

To a suspension of sodium $(77 \mathrm{mg}, 3.36 \mathrm{mmol})$ in THF $(2 \mathrm{~mL})$ at room temperature was added allyl alcohol $(0.76 \mathrm{~mL}, 11.21 \mathrm{mmol})$ dropwise to maintain a steady reaction. Once all of the sodium had dissolved, the alkoxide solution was added via cannula to a stirred solution of $25(550 \mathrm{mg}, 1.12 \mathrm{mmol})$ in THF $(11 \mathrm{~mL})$ and the mixture was stirred at room temperature for $2 \mathrm{~h}$. A saturated solution of $\mathrm{NH}_{4} \mathrm{Cl}$ (aq.) $(10 \mathrm{~mL})$ was added. The solvent was removed under reduced pressure and the crude residue was extracted with DCM $(3 \times 30 \mathrm{~mL})$. The combined organic extracts were dried $\left(\mathrm{MgSO}_{4}\right)$ filtered and concentrated under reduced pressure, giving 26 in sufficient purity without any further purification as an orange solid (525 mg, 91\%). m.p. 225-227 ${ }^{\circ}$ C; I.R. (KBr) $v_{\max } 2925,1641,1561,1487$, 1177, $858 \mathrm{~cm}^{-1},{ }^{1} \mathrm{H}$ NMR $\left(300 \mathrm{MHz}, \mathrm{CDCl}_{3}\right) \delta 8.18(\mathrm{~d}, J=8.7 \mathrm{~Hz}, 1 \mathrm{H}, \mathrm{Ar}-\mathrm{H}), 7.99(\mathrm{~d}, J=2.0$ $\mathrm{Hz}, 1 \mathrm{H}, \mathrm{Ar}-\mathrm{H}), 7.86(\mathrm{~d}, J=1.6 \mathrm{~Hz}, 1 \mathrm{H}, \mathrm{Ar}-\mathrm{H}), 7.56(\mathrm{~d}, J=1.9 \mathrm{~Hz}, 1 \mathrm{H}, \mathrm{Ar}-\mathrm{H}), 7.53$ (dd, J = 8.7, 1.7 Hz, 1H, Ar-H), 7.37-7.27 (m, 5H, $5 \times \mathrm{Ar}-\mathrm{H}), 6.32-6.20\left(\mathrm{~m}, 1 \mathrm{H}, \mathrm{CH}_{2}=\mathrm{C} \underline{\mathrm{H}}\right), 6.19(\mathrm{~s}, 2 \mathrm{H}$, $\left.\mathrm{CH}_{2} \mathrm{~N}\right), 5.56\left(\mathrm{dq}, J=17.1,1.4 \mathrm{~Hz}, 1 \mathrm{H}, \mathrm{CH}_{2}=\mathrm{CH}\right), 5.43\left(\mathrm{dq}, J=10.4,1.1 \mathrm{~Hz}, 1 \mathrm{H}, \mathrm{CH}_{2}=\mathrm{CH}\right)$, $4.99\left(\mathrm{dt}, J=5.7,1.3 \mathrm{~Hz}, 2 \mathrm{H}, \mathrm{CH}_{2}\right) ;{ }^{13} \mathrm{C} \mathrm{NMR}\left(75 \mathrm{MHz}, \mathrm{CDCl}_{3}\right) \delta 158.7$ (C5a), $158.4(\mathrm{C} 11)$, 149.4 (ArC), 148.9 (ArC), 138.6 (C4a), 135.2 (ArC), $132.0\left(\mathrm{CH}=\mathrm{CH}_{2}\right), 129.1$ (ArCH), 128.0 $(\mathrm{ArCH}), 127.9(\mathrm{ArCH}), 127.0(\mathrm{ArCH}), 126.5(\mathrm{C}), 126.1(\mathrm{ArCH}), 125.6(\mathrm{ArCH}), 125.2(\mathrm{ArC})$, 124.7 (ArC), $121.3(\mathrm{ArCH}), 119.8\left(\mathrm{CH}=\mathrm{CH}_{2}\right), 118.5(\mathrm{ArCH}), 117.0(\mathrm{ArC}), 116.0(\mathrm{ArC}), 76.1$ 
$\left(\mathrm{CH}_{2}-\mathrm{C}=\mathrm{C}\right), 49.7\left(\mathrm{CH}_{2} \mathrm{~N}\right)$; HR MS $\left(\mathrm{ES}^{+}\right) \mathrm{m} / \mathrm{z}$ calcd. for $\mathrm{C}_{25} \mathrm{H}_{18}{ }^{79} \mathrm{Br}^{35} \mathrm{Cl}_{2} \mathrm{~N}_{2} \mathrm{O} 510.9980$, found $510.9979[\mathrm{M}+\mathrm{H}]^{+}$.

3.3.10. 10b-Allyl-5-benzyl-3-bromo-7,9-dichloro-5H-indolo[2,3-b]quinolin-11(10bH)-one 27

A solution of $26(500 \mathrm{mg}, 0.98 \mathrm{mmol})$ in toluene $(10 \mathrm{~mL})$ was heated to reflux for $1.5 \mathrm{~h}$ before removing the solvent under reduced pressure. The crude product was purified by column chromatography (10-25\% EtOAc/hexanes) to give 27 as an orange-yellow solid (477 mg, 95\%). Recrystallization by slow evaporation of a solution of 27 in EtOAc/Hexane provided crystals suitable for X-ray analysis. m.p. $240{ }^{\circ} \mathrm{C}$ (dec.); I.R. $v_{\max } 1695,1543,1196$, $854 \mathrm{~cm}^{-1} ;{ }^{1} \mathrm{H}$ NMR $\left(400 \mathrm{MHz}, \mathrm{CDCl}_{3}\right) \delta 7.80(\mathrm{~d}, J=8.8 \mathrm{~Hz}, 1 \mathrm{H}, \mathrm{C} 1-\mathrm{H}), 7.59(\mathrm{~d}, J=2.0 \mathrm{~Hz}, 1 \mathrm{H}$, C10-H), 7.43-7.37 (m, 5H, $5 \times$ ArC-H), $7.33(\mathrm{~m}, 1 \mathrm{H}, \operatorname{ArC}-\mathrm{H}), 7.29-7.26(\mathrm{~m}, 2 \mathrm{H}, 2 \times$ ArC-H), $5.98\left(\mathrm{~d}, J=16.4 \mathrm{~Hz}, 1 \mathrm{H}, 1 \times \mathrm{CH}_{2} \mathrm{~N}\right), 5.38\left(\mathrm{ddt}, J=16.9,10.1,7.3 \mathrm{~Hz}, 1 \mathrm{H}, \mathrm{CH}=\mathrm{CH}_{2}\right), 5.14-5.03$ $\left(\mathrm{m}, 2 \mathrm{H}, 1 \times \mathrm{C}_{2} \mathrm{~N}, 1 \times \mathrm{CH}=\mathrm{C}_{2}\right), 4.90\left(\mathrm{dd}, J=16.8,1.3 \mathrm{~Hz}, 1 \mathrm{H}, \mathrm{CH}=\mathrm{CH}_{2}\right), 2.87(\mathrm{dd}$, $\left.J=13.4,6.9 \mathrm{~Hz}, 1 \mathrm{H}, \mathrm{CH}_{2}\right), 2.53\left(\mathrm{dd}, J=13.4,7.7 \mathrm{~Hz}, 1 \mathrm{H}, \mathrm{CH}_{2}\right) ;{ }^{13} \mathrm{C} \mathrm{NMR}\left(101 \mathrm{MHz}, \mathrm{CDCl}_{3}\right)$

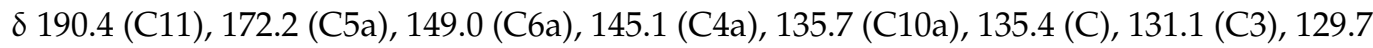
(C1), 129.2 (ArCH), 129.1 (ArCH), $129.1(\mathrm{ArC}), 128.9\left(\mathrm{C}^{\left.10 b^{\mathrm{II}}\right)}, 128.0(\mathrm{ArCH}), 126.8(\mathrm{ArCH})\right.$,

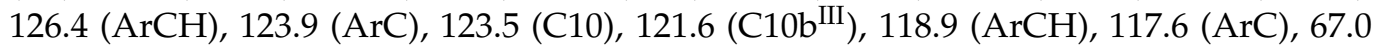
(C10b), $49.9\left(\mathrm{C}^{0} \mathrm{~b}^{\mathrm{I}}\right), 44.8\left(\mathrm{CH}_{2} \mathrm{~N}\right)$; HR MS $\left(\mathrm{ES}^{+}\right) \mathrm{m} / \mathrm{z}$ calcd. for $\mathrm{C}_{25} \mathrm{H}_{17}{ }^{79} \mathrm{Br}^{35} \mathrm{Cl}^{37} \mathrm{ClN}_{2} \mathrm{ONa}$ 534.9769 , found $534.9767[\mathrm{M}+\mathrm{Na}]^{+}$.

3.3.11. (E)-5-Benzyl-3-bromo-10b-(but-2-en-1-yl)-7,9-dichloro-5H-indolo[2,3-b]quinolin$11(10 \mathrm{bH})$-one 29

To a suspension of sodium ( $205 \mathrm{mg}, 8.93 \mathrm{mmol})$ in THF $(5 \mathrm{~mL})$ at room temperature was added $( \pm)$-3-buten-2-ol $(2.58 \mathrm{~mL}, 29.76 \mathrm{mmol})$ dropwise to maintain a steady reaction. Once all of the sodium had dissolved, the alkoxide solution was added via a cannula to a stirred solution of $25(1.46 \mathrm{~g}, 2.98 \mathrm{mmol})$ in THF $(30 \mathrm{~mL})$ and the mixture was stirred at room temperature for $2 \mathrm{~h}$. A saturated solution of $\mathrm{NH}_{4} \mathrm{Cl}($ aq.) $(30 \mathrm{~mL})$ was added before the organic solvent was removed under reduced pressure and the crude residue extracted with DCM $(3 \times 100 \mathrm{~mL})$. The combined organic extracts were dried $\left(\mathrm{MgSO}_{4}\right)$, filtered and concentrated under reduced pressure to give a crude product that contained $\mathbf{2 8}$ and 29 . This residue was redissolved in THF $(30 \mathrm{~mL})$ and the solution was heated at reflux for $1 \mathrm{~h}$ before removing the solvent under reduced pressure to give the crude product. Purification by column chromatography (10-25\% EtOAc/hexanes) gave 29 as a yellow solid (1.17 g, 75\%). m.p. $140-142{ }^{\circ} \mathrm{C} ; v_{\max } 1698,1590,1545,1196,855 \mathrm{~cm}^{-1} ;{ }^{1} \mathrm{H}$ NMR $\left(500 \mathrm{MHz}, \mathrm{CDCl}_{3}\right)$ $\delta 7.71(\mathrm{~d}, J=8.6 \mathrm{~Hz}, 1 \mathrm{H}, \mathrm{C} 1-\mathrm{H}), 7.48(\mathrm{~d}, J=2.0 \mathrm{~Hz}, 1 \mathrm{H}, \mathrm{C} 10-\mathrm{H}), 7.36-7.14(\mathrm{~m}, 8 \mathrm{H}, 8 \times$ ArC-H), $5.91\left(\mathrm{~d}, J=16.3 \mathrm{~Hz}, 1 \mathrm{H}, \mathrm{CH}_{2} \mathrm{~N}\right), 5.21\left(\mathrm{dq}, J=12.6,5.8 \mathrm{~Hz}, 1 \mathrm{H}, \mathrm{C}^{-} \mathrm{b}^{\mathrm{II}}-\mathrm{H}\right), 5.01-4.88$ $\left(\mathrm{m}, 2 \mathrm{H}, \mathrm{CH}_{2} \mathrm{~N}+\mathrm{C} \mathrm{b}^{\mathrm{III}}-\mathrm{H}\right), 2.74\left(\mathrm{dd}, J=13.2,6.4 \mathrm{~Hz}, 1 \mathrm{H}, \mathrm{C} 0 \mathrm{~b}^{\mathrm{I}}-\mathrm{H}_{2}\right), 2.35(\mathrm{dd}, J=13.2$, $\left.8.1 \mathrm{~Hz}, 1 \mathrm{H}, \mathrm{C} 10 \mathrm{~b}^{\mathrm{I}}-\mathrm{H}_{2}\right), 1.49\left(\mathrm{~d}, J=6.2 \mathrm{~Hz}, 3 \mathrm{H}, \mathrm{C} 10 \mathrm{~b}^{\mathrm{IV}}-\mathrm{H}_{3}\right) ;{ }^{13} \mathrm{C} \mathrm{NMR}\left(126 \mathrm{MHz}, \mathrm{CDCl}_{3}\right)$ $\delta 190.5$ (C11), 172.4 (C5a), 148.9 (C6a), 145.1 (C4a), 136.0 (C10a), 135.5 (C), 132.9 (C10b $\left.{ }^{\mathrm{II}}\right)$, 131.0 (C3), 129.6 (C1), $129.1(\mathrm{ArCH}), 129.0(\mathrm{ArCH}), 128.9(\mathrm{ArC}), 128.0(\mathrm{ArCH}), 126.8(\mathrm{ArCH})$,

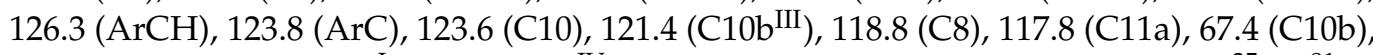

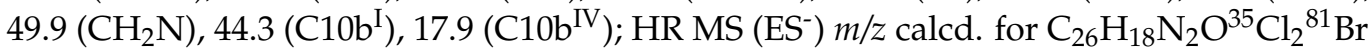
524.9959, found $524.9971[\mathrm{M}-\mathrm{H}]^{-}$.

3.3.12. 5-Benzy-3-bromo-10b-((E)-but-2-en-1-yl)-7,9-dichloro-5,10bdihydrospiro[indolo[2,3-b]quinoline-11,2'-oxirane] 31

To a solution of $29(200 \mathrm{mg}, 0.380 \mathrm{mmol})$ and chloroiodomethane $(42 \mu \mathrm{L}, 0.570 \mathrm{mmol})$ in THF $(4 \mathrm{~mL})$ at $-78{ }^{\circ} \mathrm{C}$ was added methyl lithium-lithium bromide complex $(1.5 \mathrm{M}$ in THF, $0.38 \mathrm{~mL}, 0.570 \mathrm{mmol}$ ) dropwise over $5 \mathrm{~min}$. The mixture was stirred at $-78^{\circ} \mathrm{C}$ for a further $30 \mathrm{~min}$ before removing the cold bath and stirring for a further $18 \mathrm{~h}$ at room temperature. A solution of saturated $\mathrm{NH}_{4} \mathrm{Cl}$ (aq.) $(10 \mathrm{~mL})$ was added and the mixture extracted with $\mathrm{DCM}(3 \times 10 \mathrm{~mL})$ before the combined organic extracts were dried $\left(\mathrm{MgSO}_{4}\right)$, filtered and concentrated. The crude product was purified by column chromatography 
(10-20\% EtOAc/hexanes) to give 31 as an orange solid (142 mg, 74\%). m.p. 90-93 ${ }^{\circ} \mathrm{C}$; I.R. $(\mathrm{KBr}) v_{\max } 2921,1709,1595,1550,1486,729 \mathrm{~cm}^{-1} ;{ }^{1} \mathrm{H}$ NMR $\left(400 \mathrm{MHz}, \mathrm{CDCl}_{3}\right) \delta$ 7.41-7.35 (m, 4H, $4 \times$ ArC-H), 7.33-7.28 (m, 2H, $2 \times$ ArC-H), 7.19 (dd, J = 8.1, 1.7 Hz, 1H, C2-H), $7.12(\mathrm{~d}, J=1.7 \mathrm{~Hz}, 1 \mathrm{H}, \mathrm{C} 4-\mathrm{H}), 7.11-7.05(\mathrm{~m}, 2 \mathrm{H}, 2 \times \mathrm{ArC}-\mathrm{H}), 5.89(\mathrm{~d}, J=16.2 \mathrm{~Hz}$, $\left.1 \mathrm{H}, \mathrm{CH}_{2} \mathrm{~N}\right), 5.37-5.22\left(\mathrm{~m}, 1 \mathrm{H}, \mathrm{C} 10 \mathrm{~b}^{\mathrm{III}}-\mathrm{H}\right), 4.97-4.86\left(\mathrm{~m}, 2 \mathrm{H}, \mathrm{CH}_{2} \mathrm{~N}+\mathrm{C}_{10 b} \mathrm{~b}_{-} \mathrm{H}\right), 3.03(\mathrm{~d}$, $\left.J=5.3 \mathrm{~Hz}, 1 \mathrm{H}, \mathrm{CH}_{2} \mathrm{O}\right), 2.76\left(\mathrm{ddt}, J=13.9,6.1,1.3 \mathrm{~Hz}, 1 \mathrm{H}, \mathrm{C} 10 \mathrm{~b}^{\mathrm{I}}-\mathrm{H}_{2}\right), 2.59(\mathrm{ddt}, J=13.9,6.1$, $\left.1.3 \mathrm{~Hz}, 1 \mathrm{H}, \mathrm{C} 10 \mathrm{~b}^{\mathrm{I}}-\mathrm{H}_{2}\right), 2.52\left(\mathrm{~d}, J=5.3 \mathrm{~Hz}, 1 \mathrm{H}, \mathrm{CH}_{2} \mathrm{O}\right), 1.50\left(\mathrm{~d}, J=6.0 \mathrm{~Hz}, 3 \mathrm{H}, \mathrm{CH}_{3}\right) ;{ }^{13} \mathrm{C}$ NMR (101 MHz, $\left.\mathrm{CDCl}_{3}\right) \delta 172.6$ (C5a), 151.0 (C6a), 142.0 (C4a), 137.2 (C10a), 136.1 (ArC), $130.8\left(\mathrm{C} 10 b^{\mathrm{III}}\right), 129.1$ (ArCH), $129.0(\mathrm{ArCH}), 128.4(\mathrm{ArC}), 127.7(\mathrm{ArCH}), 126.9(\mathrm{ArCH}), 126.5$ $(\mathrm{ArCH}), 125.2(\mathrm{ArCH}), 123.3(\mathrm{ArC}), 123.1(\mathrm{ArC}), 122.9\left(\mathrm{C}^{\mathrm{II}}\right), 122.1(\mathrm{C} 11 \mathrm{a}), 121.5(\mathrm{ArCH})$, 118.4 (ArCH), $59.5(\mathrm{C} 11), 56.4(\mathrm{C} 10 \mathrm{~b}), 53.2\left(\mathrm{CH}_{2} \mathrm{O}\right), 50.0\left(\mathrm{CH}_{2} \mathrm{~N}\right), 37.1\left(\mathrm{C}^{10 b^{\mathrm{I}}}\right), 17.8\left(\mathrm{C} 10 b^{\mathrm{IV}}\right)$; HR MS [APCI ${ }^{+}$: $m / z$ calcd. for $\mathrm{C}_{27} \mathrm{H}_{22}{ }^{79} \mathrm{Br}^{35} \mathrm{Cl}_{2} \mathrm{~N}_{2} \mathrm{O} 539.0287$, found $539.0275[\mathrm{M}+\mathrm{H}]^{+}$.

3.3.13. (10bR,11R)-5-Benzyl-3-bromo-10b-((E)-but-2-en-1-yl)-7,9-dichloro-10b,11-dihydro$5 H$-indolo[2,3-b]quinolin-11-yl)methanol 32

To a solution of $31(90 \mathrm{mg}, 0.167 \mathrm{mmol})$ in THF $(3 \mathrm{~mL})$ at $-78{ }^{\circ} \mathrm{C}$ was added sodium cyanoborohydride $(26 \mathrm{mg}, 0.416 \mathrm{mmol})$ and boron trifluoride diethyl etherate $(82 \mu \mathrm{L}$, $0.666 \mathrm{mmol})$. The mixture was slowly allowed to warm to room temperature over a period of $6 \mathrm{~h}$ before a saturated solution of $\mathrm{NaHCO}_{3}$ (aq.) $(6 \mathrm{~mL})$ was added. The mixture was extracted with DCM $(3 \times 10 \mathrm{~mL})$ before the combined organic extracts were dried $\left(\mathrm{MgSO}_{4}\right)$, filtered and concentrated to give the crude product. The crude reaction mixture was purified by column chromatography (20-30\% EtOAc/hexanes) to give 32 as a white solid (45 mg, 50\%). m.p. 85-86 ${ }^{\circ} \mathrm{C}$, I.R. (KBr) $v_{\max } 3419(\mathrm{OH}), 2931,1545,1486,1422,1206$ $\mathrm{cm}^{-1} ;{ }^{1} \mathrm{H}$ NMR $\left(300 \mathrm{MHz}, \mathrm{CDCl}_{3}\right) \delta 7.54(\mathrm{dd}, J=8.3,1.0 \mathrm{~Hz}, 1 \mathrm{H}, \mathrm{C} 2-\mathrm{H}), 7.38-7.24(\mathrm{~m}$, $6 \mathrm{H}, 6 \times \mathrm{ArC}-\mathrm{H}), 7.23-7.16(\mathrm{~m}, 2 \mathrm{H}, 2 \times \mathrm{ArC}-\mathrm{H}), 7.10(\mathrm{~d}, \mathrm{~J}=1.9 \mathrm{~Hz}, 1 \mathrm{H}, \mathrm{ArC}-\mathrm{H}), 5.75(\mathrm{~d}$, $\left.J=16.2 \mathrm{~Hz}, 1 \mathrm{H}, \mathrm{CH}_{2} \mathrm{~N}\right), 5.19\left(\mathrm{dq}, J=13.0,6.5 \mathrm{~Hz}, 1 \mathrm{H}, \mathrm{CH}=\mathrm{CHCH}_{3}\right), 4.80(\mathrm{~d}, J=16.2 \mathrm{~Hz}, 1 \mathrm{H}$, $\left.\mathrm{CH}_{2} \mathrm{~N}\right), 4.72-4.58\left(\mathrm{~m}, 1 \mathrm{H}, \mathrm{CH}=\mathrm{CHCH}_{2}\right), 4.53\left(\mathrm{dd}, \mathrm{J}=11.2,2.4 \mathrm{~Hz}, 1 \mathrm{H}, \mathrm{CH}_{2} \mathrm{OH}\right), 4.39-4.26$ (m, 1H, $\left.\mathrm{CH}_{2} \mathrm{OH}\right), 3.00(\mathrm{~d}, J=6.2 \mathrm{~Hz}, 1 \mathrm{H}, \mathrm{C} 11-\mathrm{H}), 2.42-2.26\left(\mathrm{~m}, 2 \mathrm{H}, \mathrm{CH}_{2}\right), 2.14$ (br., s, 1H, $\mathrm{OH}), 1.40\left(\mathrm{~d}, J=6.5 \mathrm{~Hz}, 3 \mathrm{H}, \mathrm{CH}_{3}\right) ;{ }^{13} \mathrm{C} \mathrm{NMR}\left(75 \mathrm{MHz}, \mathrm{CDCl}_{3}\right) \delta 174.4(\mathrm{C} 5 \mathrm{a}), 151.9(\mathrm{C} 6 \mathrm{a})$,

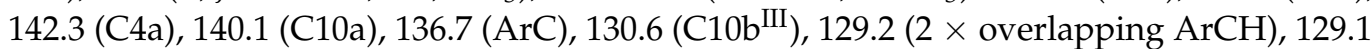

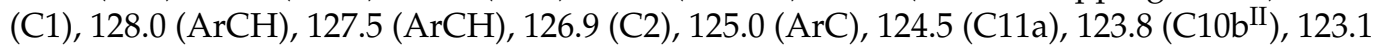
(ArC), $122.9(\mathrm{ArCH}), 122.1(\mathrm{C} 3), 119.1(\mathrm{C} 4), 61.7\left(\mathrm{CH}_{2} \mathrm{OH}\right), 56.2(\mathrm{C} 10 \mathrm{~b}), 50.8\left(\mathrm{CH}_{2} \mathrm{~N}\right), 44.0$

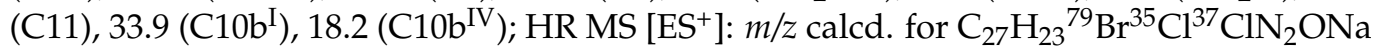
565.0239 , found $565.0220[\mathrm{M}+\mathrm{Na}]^{+}$.

3.3.14. (10bR,11R)-11-Allyl-5-benzyl-3-bromo-7,9-dichloro-10b-(2-hydroxyethyl)-10b,11dihydro-5H-indolo[2,3-b]quinolin-11-ol 40

For details of the synthesis and analysis of the diastereomeric mixtures $37 \mathbf{a} / 37 \mathbf{b}$, $38 a / 38 b$ and $39 a / 39 b$ see SI. To a solution of 39a/39b (230 mg, $0.413 \mathrm{mmol})$ in $\mathrm{MeOH}$ $(10 \mathrm{~mL})$ was added $\mathrm{NaBH}_{4}(31 \mathrm{mg}, 0.826 \mathrm{mmol})$ and the mixture was stirred at room temperature for $1 \mathrm{~h}$. A saturated solution of $\mathrm{NH}_{4} \mathrm{Cl}$ (aq.) $(10 \mathrm{~mL})$ was added and the organic solvent was removed under reduced pressure before the mixture was extracted with DCM $(3 \times 10 \mathrm{~mL})$. The combined organic extracts were dried $\left(\mathrm{MgSO}_{4}\right)$, filtered and concentrated in vacuo. The crude product was purified by column chromatography $\left(15-25 \%\right.$ EtOAc/hexanes) to give 40 as a white solid $(220 \mathrm{mg}, 95 \%)$. m.p. $=151-153{ }^{\circ} \mathrm{C}$; I.R. $(\mathrm{KBr}) v_{\max } 3163,2931,1545,1481,1418,1206,847,729 \mathrm{~cm}^{-1} ;{ }^{1} \mathrm{H}$ NMR (500 MHz, $\left.\mathrm{CDCl}_{3}\right) \delta 7.40-7.31$ (m, 6H, C8-H, C10-H, $4 \times$ ArC-H), 7.30-7.25 (m, 2H, C1-H, ArC-H), $7.19(\mathrm{dd}, J=8.1,1.7 \mathrm{~Hz}, 1 \mathrm{H}, \mathrm{C} 2-\mathrm{H}), 7.13(\mathrm{~d}, J=1.7 \mathrm{~Hz}, 1 \mathrm{H}, \mathrm{C} 4-\mathrm{H}), 5.56$ (d, $J=16.1 \mathrm{~Hz}$, $\left.1 \mathrm{H}, \mathrm{CH}_{2} \mathrm{~N}\right), 5.38\left(\mathrm{ddt}, J=17.3,10.0,7.3 \mathrm{~Hz}, 1 \mathrm{H}, \mathrm{C} 11^{\mathrm{II}}-\mathrm{H}\right), 5.22\left(\mathrm{~d}, J=16.0 \mathrm{~Hz}, 1 \mathrm{H}, \mathrm{CH}_{2} \mathrm{~N}\right)$, $4.98-4.92\left(\mathrm{~m}, 1 \mathrm{H}, \mathrm{C} 11^{\mathrm{III}}-\mathrm{H}_{2}\right), 4.73\left(\mathrm{dt}, J=17.0,1.6 \mathrm{~Hz}, 1 \mathrm{H}, \mathrm{C} 11^{\mathrm{III}}-\mathrm{H}_{2}\right), 3.60(\mathrm{ddd}, J=12.0,8.7$, $\left.3.6 \mathrm{~Hz}, 1 \mathrm{H}, \mathrm{C} 10 \mathrm{~b}^{\mathrm{II}}-\mathrm{H}_{2}\right), 3.52-3.45\left(\mathrm{~m}, 1 \mathrm{H}, \mathrm{C} 10 \mathrm{~b}^{\mathrm{II}}-\mathrm{H}_{2}\right), 2.41-2.32\left(\mathrm{~m}, 1 \mathrm{H}, \mathrm{C} 10 \mathrm{~b}^{\mathrm{I}}-\mathrm{H}_{2}\right), 2.12(\mathrm{~d}$, $\left.J=7.0 \mathrm{~Hz}, 2 \mathrm{H}, \mathrm{C} 11^{\mathrm{I}}-\mathrm{H}_{2}\right), 1.78-1.69\left(\mathrm{~m}, 1 \mathrm{H}, \mathrm{C} 10 \mathrm{~b}^{\mathrm{I}}-\mathrm{H}_{2}\right) ;{ }^{13} \mathrm{C} \mathrm{NMR}\left(126 \mathrm{MHz}, \mathrm{CDCl}_{3}\right) \delta 175.4$

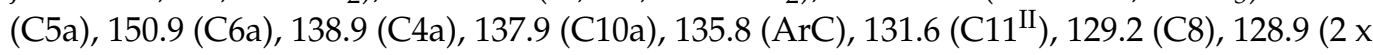


overlapping carbons $\mathrm{ArCH}, \mathrm{C} 11 \mathrm{a}), 128.4(\mathrm{ArCCl}), 128.2(\mathrm{C} 1$ or $\mathrm{ArCH}), 127.9(\mathrm{C} 1$ or $\mathrm{ArCH})$, $127.3(\mathrm{ArCH}), 126.4(\mathrm{C} 2), 122.9$ (ArCCl), 122.7 (C10), 122.3 (C3), 120.0 (C11 $1 \mathrm{III}), 118.6(\mathrm{C} 4)$, $75.3(\mathrm{C} 11), 61.3(\mathrm{C} 10 \mathrm{~b}), 58.6\left(\mathrm{C}_{10 b^{\mathrm{II}}}\right), 49.4\left(\mathrm{CH}_{2} \mathrm{~N}\right), 40.6\left(\mathrm{C}^{\mathrm{I}}\right), 35.0\left(\mathrm{C}^{\mathrm{I}} \mathrm{bb}^{\mathrm{I}}\right)$. HR MS [ES ${ }^{+}$: $\mathrm{m} / \mathrm{z}$ calcd. for $\mathrm{C}_{27} \mathrm{H}_{24}{ }^{79} \mathrm{Br}^{35} \mathrm{Cl}_{2} \mathrm{~N}_{2} \mathrm{O}_{2}$ 557.0393, found $557.0392[\mathrm{M}+\mathrm{H}]^{+}$.

3.3.15. (3aR,13bR)-13b-Allyl-9-benzyl-11-bromo-5,7-dichloro-2,3,9,13btetrahydrofuro[3,2-c]indolo [2,3-b]quinoline 41

To a solution of 40 (50 mg, $0.090 \mathrm{mmol})$ in DCM $(2 \mathrm{~mL})$ was added $p$-toluenesulfonyl chloride $(26 \mathrm{mg}, 0.134 \mathrm{mmol})$ and triethylamine $(124 \mu \mathrm{L}, 0.896 \mathrm{mmol})$ and the mixture was stirred at room temperature for $1 \mathrm{~h}$. The mixture was then heated to reflux for a further $5 \mathrm{~h}$ before cooling to room temperature and addition of a saturated solution of $\mathrm{NH}_{4} \mathrm{Cl}$ (aq.) $(5 \mathrm{~mL})$. The mixture was extracted with DCM $(3 \times 5 \mathrm{~mL})$ and the combined organic extracts were dried $\left(\mathrm{MgSO}_{4}\right)$, filtered and concentrated in vacuo. The crude product was purified by column chromatography (5-15\% EtOAc/hexanes) to give 41 as a white solid (40 mg, 83\%). Recrystallization of $\mathbf{4 1}$ by slow evaporation from ethyl acetate gave crystals of suitable quality for X-ray crystallographic analysis. m.p. $=177-179{ }^{\circ} \mathrm{C}$; I.R. (KBr) $v_{\max } 2926,1548$, 1484, 1425, 1204, 1071, 1044, $850 \mathrm{~cm}^{-1},{ }^{1} \mathrm{H}$ NMR (500 MHz, CDCl 3 ) $\delta$ 7.29-7.15 (m, 7H, C6-H, $\mathrm{C} 13-\mathrm{H}, 5 \times \mathrm{ArC}-\mathrm{H}), 7.14(\mathrm{~d}, J=2.0 \mathrm{~Hz}, 1 \mathrm{H}, \mathrm{C} 4-\mathrm{H}), 7.10(\mathrm{dd}, J=8.2,1.8 \mathrm{~Hz}, 1 \mathrm{H}, \mathrm{C} 12-\mathrm{H})$, $7.00(\mathrm{~d}, \mathrm{~J}=1.8 \mathrm{~Hz}, 1 \mathrm{H}, \mathrm{C} 10-\mathrm{H}), 5.62\left(\mathrm{~d}, \mathrm{~J}=16.1 \mathrm{~Hz}, 1 \mathrm{H}, \mathrm{CH}_{2} \mathrm{~N}\right), 5.06-4.95\left(\mathrm{~m}, 2 \mathrm{H}, \mathrm{CH}_{2} \mathrm{~N}\right.$, $\mathrm{C} 15-\mathrm{H}), 4.67-4.60\left(\mathrm{~m}, 1 \mathrm{H}, \mathrm{C} 16-\mathrm{H}_{2}\right), 4.39\left(\mathrm{dq}, \mathrm{J}=16.9,1.3 \mathrm{~Hz}, 1 \mathrm{H}, \mathrm{C} 16-\mathrm{H}_{2}\right), 4.12(\mathrm{q}, J=8.3$ $\left.\mathrm{Hz}, 1 \mathrm{H}, \mathrm{C} 2-\mathrm{H}_{2}\right), 3.74\left(\mathrm{ddd}, J=10.1,8.6,3.4 \mathrm{~Hz}, 1 \mathrm{H}, \mathrm{C} 2-\mathrm{H}_{2}\right), 2.49$ (ddd, $J=12.6,10.1,8.2 \mathrm{~Hz}$, $\left.1 \mathrm{H}, \mathrm{C} 3-\mathrm{H}_{2}\right), 2.38-2.35\left(\mathrm{~m}, 2 \mathrm{H}, 14-\mathrm{H}_{2}\right), 2.03\left(\mathrm{ddd}, J=12.2,8.2,3.4 \mathrm{~Hz}, 1 \mathrm{H}, \mathrm{C} 3-\mathrm{H}_{2}\right) ;{ }^{13} \mathrm{C}$ NMR $\left(126 \mathrm{MHz} \mathrm{CDCl}_{3}\right) \delta 171.6(\mathrm{C} 8 \mathrm{a}), 149.2$ (C7a), 139.2 (C3b), 139.0 (C9a), 134.9 (ArC), 128.9 (C15), 127.9 (C6), $127.9(\mathrm{ArCH}), 127.7(\mathrm{C} 13$ or $\mathrm{ArCH}), 127.2(\mathrm{ArCCl}), 126.7(\mathrm{C} 13$ or $\mathrm{ArCH})$, 126.1 (ArCH), 125.5 (C12), 124.8 (C13a), 122.3 (ArCCl), 121.8 (C11), 120.1 (C4), 119.2 (C16), 117.2 (C10), 85.0 (C13b), 63.3 (C2), $59.5(\mathrm{C} 3 \mathrm{a}), 48.3\left(\mathrm{CH}_{2} \mathrm{~N}\right), 40.5(\mathrm{C} 14), 36.8$ (C3); HR MS [ES ]: $m / z$ calcd. for $\mathrm{C}_{27} \mathrm{H}_{22}{ }^{79} \mathrm{Br}^{35} \mathrm{Cl}_{2} \mathrm{~N}_{2} \mathrm{O} 539.0287$, found $539.0284[\mathrm{M}+\mathrm{H}]^{+}$.

3.3.16. (R)-2-(11,11-Diallyl-5-benzyl-3-bromo-7,9-dichloro-10b,11-dihydro-5H-indolo[2,3b]quinolin-10b-yl)ethanol 35

To a solution of $41(40 \mathrm{mg}, 0.074 \mathrm{mmol})$ in DCM $(1.5 \mathrm{~mL})$ at $-78{ }^{\circ} \mathrm{C}$ was added allyltrimethylsilane $(42 \mathrm{mg}, 0.370 \mathrm{mmol})$ and $\mathrm{TiCl}_{4}(70 \mathrm{mg}, 0.370 \mathrm{mmol})$ and the mixture was stirred at $-78{ }^{\circ} \mathrm{C}$ for $4.5 \mathrm{~h}$. Methanol $(0.5 \mathrm{~mL})$ was added and the mixture was stirred for an additional $10 \mathrm{~min}$ before the cold bath was removed and a saturated solution of $\mathrm{NH}_{4} \mathrm{Cl}$ (aq.) $(5 \mathrm{~mL})$ was added. The mixture was extracted with DCM $(3 \times 5 \mathrm{~mL})$ and the combined organic extracts were dried $\left(\mathrm{MgSO}_{4}\right)$, filtered and concentrated in vacuo. The crude product was purified by column chromatography (15-30\% EtOAc/hexanes) to give 35 as a pale yellow solid $(34 \mathrm{mg}, 79 \%)$. m.p. $=73-75{ }^{\circ} \mathrm{C}$; I.R. (KBr) $v_{\max } 3389,3074$, 2921, 1607, 1548, 1486, 1422, 1206, 909, 847, 798, 729, $702 \mathrm{~cm}^{-1} ;{ }^{1} \mathrm{H} \mathrm{NMR}\left(400 \mathrm{MHz}, \mathrm{CDCl}_{3}\right)$ б 7.47-7.39 (m, 2H, $2 \times$ ArC-H), 7.36-7.27 (m, 4H, C8-H, 3 x ArC-H), 7.23 (d, J = 1.9 Hz, 1H, C4-H), 7.19 (d, J = 1.9 Hz, 1H, C10-H), 7.15 (dd, J = 8.3, 1.9 Hz, 1H, C2-H), 7.03 (d, $J=8.3 \mathrm{~Hz}, 1 \mathrm{H}, \mathrm{C} 1-\mathrm{H}), 6.09$ (ddt, $\left.J=17.1,9.6,4.9 \mathrm{~Hz}, 1 \mathrm{H}, \mathrm{C} 11^{\mathrm{II}}-\mathrm{H}\right), 5.44(\mathrm{~d}, J=15.9 \mathrm{~Hz}$, $\left.1 \mathrm{H}, \mathrm{CH}_{2} \mathrm{~N}\right), 5.38\left(\mathrm{~d}, J=17.1 \mathrm{~Hz}, 1 \mathrm{H}, \mathrm{C} 11^{\mathrm{III}}-\mathrm{H}_{2}\right), 5.28\left(\mathrm{~d}, J=15.9 \mathrm{~Hz}, 1 \mathrm{H}, \mathrm{CH}_{2} \mathrm{~N}\right), 5.17$ (d, $\left.J=10.2 \mathrm{~Hz}, 1 \mathrm{H}, \mathrm{C} 11^{\mathrm{IIIa}}-\mathrm{H}_{2}\right), 5.14-5.03\left(\mathrm{~m}, 1 \mathrm{H}, \mathrm{C} 11^{\mathrm{Ilb}}-\mathrm{H}\right), 4.82\left(\mathrm{~d}, J=10.0 \mathrm{~Hz}, 1 \mathrm{H}, \mathrm{C} 11^{\mathrm{IIIb}}-\mathrm{H}_{2}\right)$, $4.62\left(\mathrm{~d}, \mathrm{~J}=16.2 \mathrm{~Hz}, 1 \mathrm{H}, \mathrm{C} 11^{\mathrm{IIIb}}-\mathrm{H}_{2}\right), 3.17-3.05\left(\mathrm{~m}, 2 \mathrm{H}, \mathrm{C} 10 \mathrm{~b}^{\mathrm{II}}-\mathrm{H}_{2}, \mathrm{C} 11^{\mathrm{Ia}}-\mathrm{H} 2\right), 2.95$ (ddd, $\left.J=10.6,8.5,5.3 \mathrm{~Hz}, 1 \mathrm{H}, \mathrm{C} 10 \mathrm{~b}^{\mathrm{II}}-\mathrm{H} 2\right), 2.75$ (dd, $\left.J=16.9,9.2 \mathrm{~Hz}, 1 \mathrm{H}, \mathrm{C} 11^{\mathrm{Ia}}-\mathrm{H} 2\right), 2.34$ (ddd, $\left.J=13.4,8.2,5.3 \mathrm{~Hz}, 1 \mathrm{H}, \mathrm{C} 10 \mathrm{~b}^{\mathrm{I}}-\mathrm{H}_{2}\right), 2.14-2.03\left(\mathrm{~m}, 2 \mathrm{H}, \mathrm{C} 10 \mathrm{~b}^{\mathrm{I}}-\mathrm{H}_{2}, \mathrm{C} 11^{\mathrm{lb}}-\mathrm{H}_{2}\right), 1.80-1.72(\mathrm{~m}$, $\left.1 \mathrm{H}, \mathrm{C} 11^{\mathrm{lb}}-\mathrm{H}_{2}\right) ;{ }^{13} \mathrm{C}$ NMR (101 MHz, $\left.\mathrm{CDCl}_{3}\right) \delta 173.9$ (C5a), 151.6 (C6a), 140.6 (C4a), 138.9 (C10a), $135.9(\mathrm{ArCH}), 135.8\left(\mathrm{C} 11^{\mathrm{IIa}}\right), 132.6\left(\mathrm{C} 11^{\mathrm{Ilb}}\right), 129.5(\mathrm{C} 1), 129.1(\mathrm{C} 8), 128.8(\mathrm{ArCH})$, 128.1 ( $\mathrm{ArCCl}), 127.7$ (ArCH), 126.5 (C11a), 125.9 (C2), 122.8 (ArCCl), 122.2 (C10), 121.6 (C3),

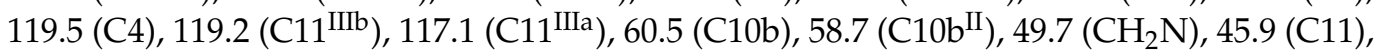
$39.9\left(\mathrm{C} 11^{\mathrm{Ib}}\right), 37.3\left(\mathrm{C} 11^{\mathrm{Ia}}\right), 35.6\left(\mathrm{C} \mathrm{bb}^{\mathrm{I}}\right)$; HR MS $\left[\mathrm{ES}^{+}\right]: \mathrm{m} / z$ calcd. for $\mathrm{C}_{30} \mathrm{H}_{28}{ }^{79} \mathrm{Br}^{35} \mathrm{Cl}_{2} \mathrm{~N}_{2} \mathrm{O}$ 581.0757 , found $581.0756[\mathrm{M}+\mathrm{H}]^{+}$. 
3.3.17. 3a-(4-Allyl-1-benzyl-7-bromo-2-(iodomethyl)-1,2,3,4-tetrahydroquinolin-4-yl)-5,7dichloro-3,3a-dihydro-2H-furo[2,3- $b$ ]indole 45

To a solution of 35 (18 mg, $0.031 \mathrm{mmol})$ in base-washed $\mathrm{CDCl}_{3}(1 \mathrm{~mL})$ was added NIS (22 $\mathrm{mg}, 0.098 \mathrm{mmol}$ ) and the mixture was stirred at room temperature for $3 \mathrm{~h}$. A saturated solution of $\mathrm{Na}_{2} \mathrm{~S}_{2} \mathrm{O}_{3}$ (aq.) ( $2 \mathrm{~mL}$ ) was added and the mixture was stirred for a further $10 \mathrm{~min}$ before being extracted with DCM $(3 \times 2 \mathrm{~mL})$. The combined organic extracts were dried $\left(\mathrm{MgSO}_{4}\right)$, filtered and concentrated in vacuo. The crude product was purified by column chromatography ( $\mathrm{Et}_{3} \mathrm{~N}$ washed silica, 5-15\% EtOAc/hexanes), giving 45 as a white solid (11 mg, 50\%). I.R. (KBr) $v_{\max } 3320,3074,2921,1607,1548,1486,1420,1255,1206,911$, 847, 798, $729 \mathrm{~cm}^{-1},{ }^{1} \mathrm{H}$ NMR $\left(500 \mathrm{MHz} \mathrm{CDCl}_{3}\right) \delta 7.40(\mathrm{~d}, \mathrm{~J}=2.0 \mathrm{~Hz}, 1 \mathrm{H}, \mathrm{C6}-\mathrm{H}), 7.38-7.27$ $(\mathrm{m}, 6 \mathrm{H}, \mathrm{C} 4-\mathrm{H}, 5 \times \mathrm{ArC}-\mathrm{H}), 7.19\left(\mathrm{~d}, J=8.3 \mathrm{~Hz}, 1 \mathrm{H}, \mathrm{C}^{\prime}-\mathrm{H}\right), 6.93(\mathrm{dd}, J=8.3,2.0 \mathrm{~Hz}, 1 \mathrm{H}$, $\left.\mathrm{C6}^{\prime}-\mathrm{H}\right), 6.82\left(\mathrm{~d}, J=1.9 \mathrm{~Hz}, 1 \mathrm{H}, \mathrm{C} 8^{\prime}-\mathrm{H}\right), 5.70$ (dddd, $\left.J=17.8,10.1,7.9,5.2 \mathrm{~Hz}, 1 \mathrm{H}, \mathrm{C} 4^{\prime \mathrm{II}}-\mathrm{H}\right)$, 5.28-5.17 (m, 2H, C4 $\left.{ }^{\prime I I I}-\mathrm{H}_{2}\right), 4.64\left(\mathrm{~d}, J=17.9 \mathrm{~Hz}, 1 \mathrm{H}, \mathrm{CH}_{2} \mathrm{~N}\right), 4.46\left(\mathrm{~d}, J=17.8 \mathrm{~Hz}, 1 \mathrm{H}, \mathrm{CH}_{2} \mathrm{~N}\right)$, $4.31\left(\mathrm{t}, J=9.1 \mathrm{~Hz}, 1 \mathrm{H}, \mathrm{C} 2-\mathrm{H}_{2}\right), 3.51-3.42\left(\mathrm{~m}, 1 \mathrm{H}, \mathrm{C} 2^{\prime}-\mathrm{H}\right), 3.26(\mathrm{dd}, J=14.4,5.2 \mathrm{~Hz}, 1 \mathrm{H}$, $\left.\mathrm{C}^{\prime}{ }^{\mathrm{I}}-\mathrm{H}_{2}\right), 3.07$ (ddd, $\left.J=10.0,8.5,6.3 \mathrm{~Hz}, 1 \mathrm{H}, \mathrm{C} 2-\mathrm{H}_{2}\right), 3.01\left(\mathrm{dd}, J=9.7,2.7 \mathrm{~Hz}, 1 \mathrm{H}, \mathrm{CH}_{2} \mathrm{I}\right)$, $2.54\left(\mathrm{q}, J=7.2 \mathrm{~Hz}, 3 \mathrm{H}, 1 \times \mathrm{C}^{2}-\mathrm{H}_{2}, 1 \times \mathrm{C}^{\prime \mathrm{I}}-\mathrm{H}_{2}, 1 \times \mathrm{CH}_{2} \mathrm{I}\right), 2.09(\mathrm{dt}, J=13.5,10.0 \mathrm{~Hz}, 1 \mathrm{H}$, $\left.\mathrm{C} 3-\mathrm{H}_{2}\right), 1.58\left(\mathrm{dd}, J=8.9,6.7 \mathrm{~Hz}, 2 \mathrm{H}, \mathrm{C}^{\prime}-\mathrm{H}_{2}\right) ;{ }^{13} \mathrm{C} \mathrm{NMR}\left(126 \mathrm{MHz}, \mathrm{CDCl}_{3}\right) \delta 193.6(\mathrm{C} 8 \mathrm{a})$, 153.8 (C7a), 149.4 (C8a'), 140.3 (C3b), 139.0 (ArC), $132.2\left(\mathrm{C4}^{\prime \mathrm{II}}\right), 129.5(\mathrm{C} 6), 129.1$ (C5'), 128.7 $(\mathrm{ArCH}), 128.4(\mathrm{ArCCl}), 127.2(\mathrm{ArCH}), 126.5(\mathrm{ArCH}), 124.3(\mathrm{ArCCl}), 123.6(\mathrm{C} 4), 123.5\left(\mathrm{C}^{\prime}\right)$,

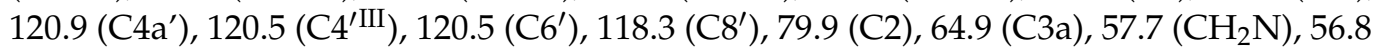
$\left(\mathrm{C}^{\prime}\right), 45.0\left(\mathrm{C}^{\prime}\right), 38.5\left(\mathrm{C}^{\prime \prime}\right), 37.8\left(\mathrm{C}^{\prime}\right), 27.5(\mathrm{C} 3), 13.3\left(\mathrm{CH}_{2} \mathrm{I}\right)$; HR MS [ES $\left.{ }^{+}\right]: \mathrm{m} / z$ calcd. for $\mathrm{C}_{30} \mathrm{H}_{26}{ }^{79} \mathrm{Br}^{35} \mathrm{Cl}_{2} \mathrm{IN}_{2} \mathrm{ONa} 728.9548$, found $728.9554[\mathrm{M}+\mathrm{H}]^{+}$.

\section{Conclusions}

The natural product perophoramidine (1) continues to challenge synthetic organic chemists. This report describes how the required presence of the two chlorines and one bromine in $\mathbf{1}$ forced us into a change in synthetic approach compared to our previous reports on dehaloperophoramidine (2). The optimization of an NCS-mediated intramolecular C-N bond-forming reaction at the indole 2-position was achieved and led to a suitably halogensubstituted indoloquinoline core structure. Two attempts to progress further towards the structure of perophoramidine (1) are also described. In one of these approaches, the presence of the halogens blocked a previously observed undesired reaction pathway. However, an alternative reaction pathway occurred, leading to a major rearrangement of the core structure of the molecule and delivering an interesting furo[2,3-b]indole-containing structure. Throughout this work, small-molecule X-ray crystallographic analysis has proved essential.

Supplementary Materials: Schemes S1-S10, Tables S1-S3, Figures S1-S5 and additional experimental details. CIF files for X-ray structure of 27 and 41.

Author Contributions: Conceptualization, N.J.W.; methodology, C.A.J., D.B.C., T.L., A.M.Z.S. and N.J.W.; investigation, C.A.J., D.B.C., T.L., A.M.Z.S. and N.J.W.; data curation, D.B.C., T.L. and A.M.Z.S.; writing—original draft, N.J.W.; writing—review and editing, D.B.C. and N.J.W.; supervision, N.J.W.; project administration, N.J.W.; funding acquisition, N.J.W. All authors have read and agreed to the published version of the manuscript.

Funding: This research was funded by EPSRC with a DTA studentship for C.A.J. And The APC was funded by University of St Andrews.

Institutional Review Board Statement: Not applicable.

Informed Consent Statement: Not applicable.

Data Availability Statement: Data is contained within the article or supplementary material.

Acknowledgments: We would like to thank and acknowledge the important contribution made to the X-ray crystallographic analysis component of work in this manuscript and other projects in our group by David Cordes, a long term colleague of Alex Slawin. 
Conflicts of Interest: The authors declare no conflict of interest.

Sample Availability: Samples of the compounds are not available from the authors.

\section{References}

1. Verbitski, S.M.; Mayne, C.L.; Davis, R.A.; Concepcion, G.P.; Ireland, C.M. Isolation, structure determination, and biological activity of a novel alkaloid, perophoramidine, from the Philippine ascidian Perophora namei. J. Org. Chem. 2002, 67, 7124-7126. [CrossRef]

2. Siengalewicz, P.; Gaich, T.; Mulzer, J. It all began with an error: The nomofungin/communesin story. Angew. Chem. Int. Ed. 2008, 47, 8170-8176. [CrossRef]

3. Robinson, R.; Teuber, H.J. Reactions with nitrosodisulfonate. IV. Calycanthine and calycanthidine. Chem. Ind. 1954, 46, 783-784.

4. Woodward, R.B.; Yang, N.C.; Katz, T.J.; Clark, V.M.; Harley-Mason, J.; Ingleby, R.F.; Shepard, N. Calycanthine: The structure of the alkaloid and its degradation product, calycanine. Proc. Chem. Soc. 1960, 76-78.

5. Hendrickson, B.; Rees, R.; Goschke, R.R. Total synthesis of the calycanthaceous alkaloids. Chimonanthine. Proc. Chem. Soc. 1962, 383-384.

6. Hamor, T.A.; Robertson, J.M.; Shrivastava, H.N.; Silverton, J.V. The structure of calycanthine. Proc. Chem. Soc. 1960, 78-80.

7. Hamor, T.A.; Robertson, J.M. The structure of calycanthine. X-ray analysis of the dihydrobromide dehydrate. J. Chem. Soc. 1962, 194-205. [CrossRef]

8. Grant, I.J.; Hamor, T.A.; Robertson, J.M.; Sim, G.A. Structure of chimonanthine. Proc. Chem. Soc. 1962, $148-149$.

9. Grant, I.J.; Hamor, T.A.; Robertson, J.M.; Sim, G.A. The structure of chimonanthine. X-ray analysis of chimonanthine dihydrobromide. J. Chem. Soc. 1965, 5678-5696. [CrossRef]

10. Verotta, L.; Pilati, T.; Tato, M.; Elisabetsky, E.; Amador, T.A.; Nunes, D.S. Pyrrolidinoindoline Alkaloids from Psychotria colorata. J. Nat. Prod. 1998, 61, 392-396. [CrossRef]

11. Fuchs, J.R.; Funk, R.L. Total Synthesis of ( \pm )-Perophoramidine. J. Am. Chem. Soc. 2004, 126, 5068-5069. [CrossRef] [PubMed]

12. Wu, H.; Xue, F.; Xiao, X.; Qin, Y. Total Synthesis of (+)-Perophoramidine and Determination of the Absolute Configuration. J. Am. Chem. Soc. 2010, 132, 14052-14053. [CrossRef]

13. Zhang, H.; Hong, L.; Kang, H.; Wang, R. Construction of Vicinal All-Carbon Quaternary Stereocenters by Catalytic Asymmetric Alkylation Reaction of 3-Bromooxindoles with 3-Substituted Indoles: Total Synthesis of (+)-Perophoramidine. J. Am. Chem. Soc. 2013, 135, 14098-14101. [CrossRef]

14. Han, S.-J.; Vogt, F.; May, J.A.; Krishnan, S.; Gatti, M.; Virgil, S.C.; Stoltz, B.M. Evolution of a Unified, Stereodivergent Approach to the Synthesis of Communesin F and Perophoramidine. J. Org. Chem. 2015, 80, 528-547. [CrossRef]

15. Han, S.-J.; Vogt, F.; Krishnan, S.; May, J.A.; Gatti, M.; Virgil, S.C.; Stoltz, B.M. A Diastereodivergent Synthetic Strategy for the Syntheses of Communesin F and Perophoramidine. Org. Lett. 2014, 16, 3316-3319. [CrossRef]

16. Trost, B.M.; Osipov, M.; Kruger, S.; Zhang, Y. A catalytic asymmetric total synthesis of (-)-perophoramidine. Chem. Sci. 2015, 6, 349-353. [CrossRef]

17. Artman, G.D., III; Weinreb, S.M. An Approach to the Total Synthesis of the Marine Ascidian Metabolite Perophoramidine via a Halogen-Selective Tandem Heck/Carbonylation Strategy. Org. Lett. 2003, 5, 1523-1526. [CrossRef] [PubMed]

18. Wu, L.; Zhang, Q.-R.; Huang, J.-R.; Li, Y.; Su, F.; Dong, L. The application of Morita-Baylis-Hillman reaction: Synthetic studies on perophoramidine. Tetrahedron 2017, 73, 3966-3972. [CrossRef]

19. Sabahi, A.; Novikov, A.; Rainier, J.D. 2-Thioindoles as precursors to spiro-fused indolines: Synthesis of ( \pm )-dehaloperophoramidine. Angew. Chem. Int. Ed. 2006, 45, 4317-4320. [CrossRef]

20. Ishida, T.; Ikota, H.; Kurahashi, K.; Tsukano, C.; Takemoto, Y. Dearomatizing Conjugate Addition to Quinolinyl Amidines for the Synthesis of Dehaloperophoramidine through Tandem Arylation and Allylation. Angew. Chem. Int. Ed. 2013, 52, 10204-10207. [CrossRef] [PubMed]

21. Wilkie, R.P.; Neal, A.R.; Johnston, C.A.; Voute, N.; Lancefield, C.S.; Stell, M.D.; Medda, F.; Makiyi, E.F.; Turner, E.M.; Ojo, S.O.; et al. Total synthesis of dehaloperophoramidine using a highly diastereoselective Hosomi-Sakurai reaction. Chem. Commun. 2016, 52, 10747-10750. [CrossRef]

22. Hoang, A.; Popov, K.; Somfai, P. An Efficient Synthesis of ( \pm )-Dehaloperophoramidine. J. Org. Chem. 2017, 82, 2171-2176. [CrossRef] [PubMed]

23. Voute, N.; Philp, D.; Slawin, A.M.Z.; Westwood, N.J. Studies on the Claisen rearrangements in the indolo[2,3-b]quinoline system. Org. Biomol. Chem. 2010, 8, 442-450. [CrossRef] [PubMed]

24. Malgesini, B.; Forte, B.; Borghi, D.; Quartieri, F.; Gennari, C.; Papeo, G. A Straightforward Total Synthesis of (-)-Chaetominine. Chem. Eur. J. 2009, 15, 7922-7929. [CrossRef]

25. Arcadi, A.; Bianchi, G.; Inesi, A.; Marinelli, F.; Rossi, L. Electrochemical-mediated cyclization of 2-alkynylanilines: A clean and safe synthesis of indole derivatives. Eur. J. Org. Chem. 2008, 5, 783-787. [CrossRef]

26. Alfonsi, M.; Arcadi, A.; Aschi, M.; Bianchi, G.; Marinelli, F. Gold-Catalyzed Reactions of 2-Alkynyl-phenylamines with $\alpha, \beta$-Enones. J. Org. Chem. 2005, 70, 2265-2273. [CrossRef]

27. Bartoli, G.; Palmieri, G.; Bosco, M.; Dalpozzo, R. The reaction of vinyl Grignard reagents with 2-substituted nitroarenes: A new approach to the synthesis of 7-substituted indoles. Tetrahedron Lett. 1989, 30, 2129-2132. [CrossRef] 
28. Teng, X.; Degterev, A.; Jagtap, P.; Xing, X.; Choi, S.; Denu, R.; Yuan, J.; Cuny, G.D. Structure-activity relationship study of novel necroptosis inhibitors. Bioorg. Med. Chem. Lett. 2005, 15, 5039-5044. [CrossRef] [PubMed]

29. Vilsmeier, A.; Haack, A. Über die einwirkung von halogenphosphor auf alkyl-formanilide. Eine neue methode zur darstellung sekundärer und tertiärer p-alkylamino-benzaldehyde. Eur. J. Org. Chem. 1927, 60, 119-122. [CrossRef]

30. Flatt, A.K.; Yao, Y.; Maya, F.; Tour, J.M. Orthogonally Functionalized Oligomers for Controlled Self-Assembly. J. Org. Chem. 2004, 69, 1752-1755. [CrossRef]

31. Sapountzis, I.; Knochel, P. General preparation of functionalized o-nitroarylmagnesium halides through an iodine-magnesium exchange. Angew. Chem. Int. Ed. 2002, 41, 1610-1611. [CrossRef]

32. Sapountzis, I.; Dube, H.; Lewis, R.; Gommermann, N.; Knochel, P. Synthesis of Functionalized Nitroarylmagnesium Halides via an Iodine-Magnesium Exchange. J. Org. Chem. 2005, 70, 2445-2454. [CrossRef] [PubMed]

33. Griffith, W.P.; Ley, S.V.; Whitcombe, G.P.; White, A.D. Preparation and use of tetra-n-butylammonium per-ruthenate (TBAP reagent) and tetra-n-propylammonium per-ruthenate (TPAP reagent) as new catalytic oxidants for alcohols. Chem. Commun. 1987, 21, 1625-1627. [CrossRef]

34. Boros, E.E.; Thompson, J.B.; Katamreddy, S.R.; Carpenter, A.J. Facile Reductive Amination of Aldehydes with Electron-Deficient Anilines by Acyloxyborohydrides in TFA: Application to a Diazaindoline Scale-Up. J. Org. Chem. 2009, 74, 3587-3590. [CrossRef]

35. Mangette, J.E.; Chen, X.; Krishnamoorthy, R.; Samuel, V.A.; Csakai, A.J.; Camara, F.; Paquette, W.D.; Wang, H.-J.; Takahashi, H.; Fleck, R.; et al. 2-Trifluoroacetyl aminoindoles as useful intermediates for the preparation of 2-acylamino indoles. Tetrahedron Lett. 2011, 52, 1292-1295. [CrossRef]

36. Newhouse, T.; Lewis, C.A.; Eastman, K.J.; Baran, P.S. Scalable Total Syntheses of N-Linked Tryptamine Dimers by Direct Indole-Aniline Coupling: Psychotrimine and Kapakahines B and F. J. Am. Chem. Soc. 2010, 133, 7119-7137. [CrossRef] [PubMed]

37. Bergman, J.; Engqvist, R.; Stalhandske, C.; Wallberg, H. Studies of the reactions between indole-2,3-diones (isatins) and 2aminobenzylamine. Tetrahedron 2003, 59, 1033-1048. [CrossRef]

38. Coste, A.; Karthikeyan, G.; Couty, F.; Evano, G. Second-generation, biomimetic total synthesis of chaetominine. Synthesis 2009, 17, 2927-2934. [CrossRef]

39. Ohno, M.; Spande, T.F.; Witkop, B. Cyclization of tryptophan and tryptamine derivatives to pyrrolo[2,3-b]indoles. J. Am. Chem. Soc. 1968, 90, 6521-6522. [CrossRef]

40. Li, Y.; Dolphin, D.; Patrick, B.O. Synthesis of a $\mathrm{BF}_{2}$ complex of indol-2-yl-isoindol-1-ylidene-amine: A fully conjugated azadipyrromethene. Tetrahedron Lett. 2010, 51, 811-814. [CrossRef]

41. Seo, J.H.; Artman, G.D., III; Weinreb, S.M. Synthetic Studies on Perophoramidine and the Communesins: Construction of the Vicinal Quaternary Stereocenters. J. Org. Chem. 2006, 71, 8891-8900. [CrossRef] [PubMed]

42. Voute, N.; Neal, A.R.; Medda, F.; Johnston, C.A.; Slawin, A.M.Z.; Westwood, N.J. From one to two quaternary centers: Ester or nitrile $\alpha$-alkylation applied to bioactive alkaloids. Tetrahedron 2018, 74, 7399-7407. [CrossRef]

43. Bowden, K.; Heilbron, I.M.; Jones, E.R.H. 13. Researches on acetylenic compounds. Part I. The preparation of acetylenic ketones by oxidation of acetylenic carbinols and glycols. J. Chem. Soc. 1946, 39-45. [CrossRef]

44. Johnston, C.A.; Wilkie, R.P.; Krauss, H.; Neal, A.R.; Slawin, A.M.Z.; Lebl, T.; Westwood, N.J. Polycyclic ethers and an unexpected dearomatisation reaction during studies towards the bioactive alkaloid, perophoramidine. Tetrahedron 2018, 74, 3339-3347. [CrossRef]

45. Freeman-Cook, K.D.; Halcomb, R.L. A Symmetry-Based Formal Synthesis of Zaragozic Acid A. J. Org. Chem. 2000, 65, 6153-6159. [CrossRef] [PubMed]

46. CrystalClear-SM Expert v2.0rc13; Rigaku Americas: The Woodlands, TX, USA; Rigaku Corporation: Tokyo, Japan, 2009.

47. Beurskens, P.T.; Beurskens, G.; de Gelder, R.; Garcia-Granda, S.; Gould, R.O.; Israel, R.; Smits, J.M.M. DIRDIF-99; Crystallography Laboratory, University of Nijmegen: Nijmegen, The Netherlands, 1999.

48. Sheldrick, G.M. Crystal structure refinement with SHELXL. Acta Crystallogr. Sect. C 2015, 71, 3-8. [CrossRef]

49. CrystalStructure v4.3.0; Rigaku Americas: The Woodlands, TX, USA; Rigaku Corporation: Tokyo, Japan, 2018. 